$$
\text { Conf. } 340553--82
$$

UCRL-JC-115352

PREPRINT

\title{
Evaluation of Thermo-Hydrological \\ Performance in Support of the Thermal Loading Systems Study
}

Thomas A. Buscheck

John J. Nitao Steven F. Saterlie

\section{RECEIVED Nor og \\ OSTI}

This paper was prepared for submittal to the

American Nuclear Society

International High Level Radioactive Waste Management Conference

Las Vegas, Nevada

May 22-26, 1994

January 1994 


\section{DISCLAIMER}

This document was prepared as an accounl of work sponsored by an agency of the United Slates Government. Neither the Uniled Slates Governmeni nor the University of Califomia nor any of their employees, makes any warranty, express or implied, or assumes any legal liability or responsibility for the accuracy, completeness, or use fulness of any information, apparatus, producl, or process disclosed, or represents that its use would not infringe privatcly owned rights. Reference herein to any specific commercial product, process, or service by trade name, trademark, manufacturer, or otherwise, does not necessarily constitute or imply ils endorsement, recommendation, or favoring by the Uniled Stales Government or the University of California. The views and opinions of authors expressed herein do not necessarily state or refieut those of the United States Govemment or the University of California, and shall not be used for advertising or product endorsement purposes. 


\section{Contents}

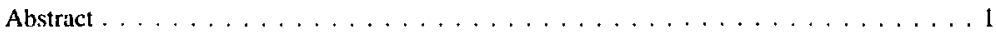

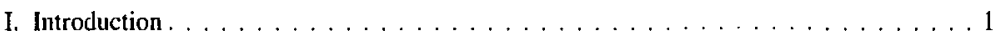

II. Thermal Loading Strategies $\ldots \ldots \ldots \ldots \ldots \ldots \ldots \ldots \ldots \ldots$

III. Numerical Models, Physical Data, and Assumptions $\ldots \ldots \ldots \ldots \ldots \ldots$

III.A V-TOUGH Hydrothermal Flow Code $\ldots \ldots \ldots \ldots \ldots \ldots \ldots$

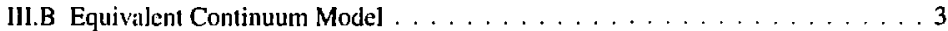

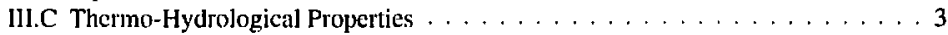

III.D Initial and Boundary Conditions . . . . . . . . . . . . 4

III.E Repository-Scale Models . . . . . . . . . . . . . . . . . , . , 4

Ill.F Sub-Repository-Scale Models . . . . . . . . . . . . . . 4

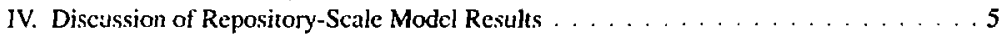

IV.A Thermo-Hydrological Behavior $\ldots \ldots \ldots \ldots \ldots \ldots \ldots \ldots \ldots \ldots$

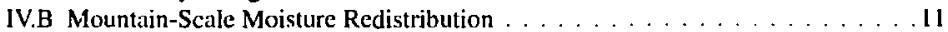

V. Discussion of Sub-Repository-Scale Model Results . . . . . . . . . . . . 15

V.A Temperature History in the Vicinity of the Emplacement Drift . . . . . . . 15

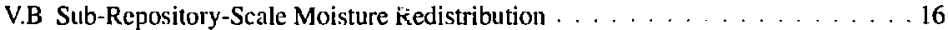

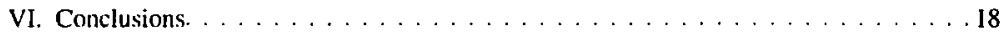

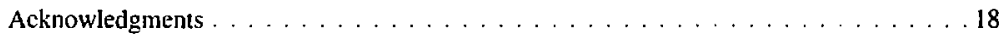

References. . . . . . . . . . . . . . . . . . 18 


\title{
Evaluation of Thermo-Hydrological Performance in Support of the Thermal Loading Systems Study
}

\author{
Thomas A. Buscheck and Jolm J. Ninow \\ Earth Sciences Department, L-206, P.O. Box 808 \\ Lawrence Livermore National Laboratory, Livermore, CA 9455 I \\ telephone: $(510)$ 42.3-9390, (510) 423-0297 \\ Stere'n F. Saterlie \\ TRW Environtmental Safety Systems \\ 101 Convention Center Drive. Suite P-1 10/Mailstop 423 \\ Las Vegas, NV 89109 \\ telephone: (702) $79+5376$
}

\begin{abstract}
Heal generated as a result of emplacing spent nuclear fuel will significantly affect the pre- and post-closure performance of the Mined Geological Disposal System (MGDS) at the potential repository site in Yucca Mountain. Understanding thermo-hydrological behavior under repository thermal loads is essential in (a) planning and conducting the sile characterization and testing program, (b) designing the reposilory and engineered barrier system, and (c) assessing performance. The grealest concem for hydrological performance is sources of water that would contact a waste package, aceelerate its failure rale, and eventually transport radionuclides to the water table. The primary sources of liquid water are: (I) natural infiltration. (2) condensatc generated under boiling conditions, and (3) condensate generated under sub-boiling conditions. Buoyant vapor flow, occurring either on a sub-repository scile or son a mountain seale. may affect the generation of the second and third sources of liquid water. A system of connected tractures facilitates repository-heal-driven gas and liquid flow is well as natural infiltration. With the use of repository-seale and sub-repository-scale models, we analyze thermo-hydro]ogical behuvior for Arcal Mass Loadings (AMLs) of 24.2, 35.9, 55.3, 83.4, and I 10.5 MTU/acre for a wide range of bulk permeability. We examine the temporal and spatial extent of the temperature and saturation changes during the first $100,000 \mathrm{yr}$. We also examine the sensitivity of mountain scale moisture redistribution to a range of AMLs and bulk permeabilities. In addition, we investigate how boiling and buoyant, gasphase convection influence thermo-hydrological behavior in the vicinity of emplacement drifts eonlaining spent nuclear fuel. The effort was done in support of a thermal loading systems study being performed to cvaluate the impact of various thermal loads on the MGDS.
\end{abstract}

\section{Intreduction}

The U.S. Department of Energy is investigating the suilability of Yucea Mountain as a potential site for the nation's first high-level nuclear waste repository. The site consists of a serics of fractured. nonwelded to densely welded tuff unils and is located about $120 \mathrm{~km}$ northwest of Las Vegas. Nevada, in an area of uninhabited descrt.' The potential mposilory localion is in Topopah Spring moderatcly to denscly welded tuft, approximately $350 \mathrm{~m}$ below the ground surface and $225 \mathrm{~m}$ above the water table. ${ }^{2}$ Favorable aspects of Yucca Mountain relate primarily to its arid nature. which results in unsaturated conditions at the potemtial repository horizon.

Heal gentraled as at result of emplacing spent nuclear fuel (SNF) will play a significanl role in the pre- and postclosure performance of the Mined Geological Disposal System (MGDS) at the potential repasitory site in Yucca Mountain. Underslanding the effects of thermal londing on the MGDS will be essential to (1) the design of a repository and engineered barrier system that will meet the necessary requirements, and (2) the demonstration, with adequate confidence, that the MGDS meets regulatory compliance. Achicving an understanding of the effects of thermal loading will reg̣uire inlegration of detailed modeling studies, a comprehensive testing and characterizalion program. and performance assessments. The purpose of this paper is to discuss the modeling and analysis of thermo-hydrological behavior at Yucca Mountain that was conducted in support of the 1993 Thernal Loading Systems Study. ${ }^{3}$

This paper examines the effects of repository-heatdriven hydruthermal flow in Yucea Mountain over a wide range of thermal loading conditions in the repository. In the failure scenario of greatest concern, water would contact at wistc package (WP), accelcrate its 
failure ratc, and eventually transport radionuclides to the water lable. Anelyses have shown that the only significunt source of mobile liquid water is from fracture flow, originating from:

(1) meteoric sources,

(2) condensatc generaled under boiling couditions, and

(3) condensatc generated under smb-briling condilioms. The first sounce of licpuid water arises from the ambient system, whilt the second and third sources are generated by repository heat. Bupyant vapor flow, accurring either on a sub-rcpository scalc or on a mountain scalc, may play an important role in the gencration of the sccond and third sourtes of liquid water. The likelihood of buoyant vapor flow generating significant quantities of condensate depends on whether fracture networks result in a bulk permeability, $k_{b}$, that is sufficiently large and sufticicritly connected over the length scales at which busyant convection oceurs. + Zones of sharply contrasting $k_{b}$ also influence condensute generation and drainage under both boiling and sub-boiling conditions. Of particular concem are condjtions that promole the focusing of vapor flow and condensale drainage. Whether this focusing may result in persistent dripping onto WPs depends on the degree of heterogemeity of fracture permeability and connectivity, and the local thermal loading conditions, ${ }^{4}$

In addition to the effect of repository heal on generating vapor and condensate flow. heat may also change the propenies of the fractured rock. Repository-hent-driven geochemical or geomechanical cltanges may, under some situations, alter hydrologica] propertics (c.g.. $k_{h}$ ) and transport properties (e.g., retardation factor, $K_{\mathrm{d}}$ ). These changes may cither improve or degrade waste containment and isolation, depending on where and when they occur. It will be nccessary to understand and quantify these processes to be able to account for their impact on hydrothermal behavior and the performance of the MGDS.

The models used in Ihis study are similar to those used in preceding studies. ${ }^{-x}$ As in past work. ${ }^{-8}$ we use the tcrm A real Mass Loading (AML) as a synonym for thermal loading conditions. Therefore, a high thermal londing case is referred to as a high-AML case and a low thermal loading case as a low-AML case. For a given bumup [expressed as megawatt-days per metric ton of initial heavy metal (MWd/MTU)], the most useful maeroseopic therma] loading parameler in analyzing long- $1 \mathrm{~cm}$ thermal performance is the AML lexpressed in metric tons of uranium per acre (MTU/acre)]. Generally, carly-temperature performance (including the peak temperature, $T_{p \text { pal }}$ ) is sensitive to the age of SNF, while the duration of the boiling period, ibp, and post-boiling-period thermal performance are determined by the AML and are insensilive to SNF age. Consequently, we prefer using AML to identify the thenmal loading conditions rather than the Areal Power Densily [(APD) expressed in kW/acre].
Because of the widespread interest in the spatial and temporal extent of the effects of repository heat, this report cmphasizes the details of the perturbed temperature and saturation distributions for a wide range of AMLs. Less emphasis is plated on deseribing the thermo-hydrological flow processics and regimes. The reader is encouraged to read Ref. 9 for a more thorough discussion of these processes and regimes.

\section{Thermal Loading Strategies}

The extent to which the three major sources of fracture flow al Yucca Mountain may impact waste package integrity, waste-form dissolution, and radionuclide migration is eritically dependent on site conditions as well as on the thermal loading stralegy that will eventually be adopted fot the MGDS. With respect to repesitory-heat-driven, thermo-hydrological performance, then: are three primary thermal loading strategies (or options). These three strategics are best framed as three fundamental yuestions:

(1) Can the thermal load be limited and distributed such that it has a negligible impact on hydrological performunce?

(2) For intermediate themal loads, will the impacl of thermo-hydrological processes and our understanding of those processes allow us to demonstrale that the MGDS meels regulatory compliance?

(3) For higher thermal louds, which could generate cxtended-dry conditions, will the impact of thermohydrological processes and our understanding of those processes allow us to demonstrate that the MGDS meets regulatory compliance?

The goal of the first thermal loading stratcgy is to minimize the hydrological impact of repository heat so that the primary concern in assessing hydrological performance is the ambient hydrological system. Therefore, this strategy reyutres that (1) we demonstrate that repository heat has a negligible impaci on hydrological performance, and (2) the behavior of the ambient hydrological system and our understanding of that behavior are sufficient to demonstrate that the MGDS mects regulatory compliance. The motivation for this stralcgy is to avoid any potenlially adverse effects of repository heul.

The goal of the third thennal loading strategy is to demonstrate that, for some period of time, repository heat is capable of dominating the ambient system with abovebouling conditions surrounding the repository. Ideally, this would result in (1) the absence of liguid water in the vicinity of the wasle packages as long as boiling persists. and (2) the contimuation of sub-ambient liquid situration conditions for some time following the above-boiling period without incurring adverse effects that may offset the benefits of dry-out. The primary motivations for this sirategy are to (a) minimize the sensitivity of reposilory 
perfornance to hydrological variability, (b) extend the period of radionuclide containmenl in the engineered burrier system, and. (c) during the period of radionuclide migration, reduce two factors: the probability of water contacting waste packages, and the flow rates associated with transport.

The second thermal loading strategy falls between the first and third strategies. All three strategies require an adequitc understanding of both the ambient hydrological system and how heat perturbs fluid flow in that system.

It is important to note that what effectively constiIutes il "cold," ambient-system-dominated repository or a "hot," extended-dry repository is not well understood. Presently. we lack adequate knowledge of ambient site condilions to define where the transitions from cold to inlermedialc or from intermediatc to hot thermal loads occur. We have analyzed how silc conditions will influence the delermination of these iransitions. ${ }^{4.9}$ In parlicular, the influence of buoyant. gas-phase convection and how hydrogeological helerogeneity may focts vapor and condensate flow are critical to determining what thermal loads are su[ficiently "cold" to render hydrothemal impucts of repository heat as negligible. The influence of these processes will also liargely delermint what thermal loads are sufficiently "hol" (or whether any such thermal loads cxist) to allow us to demonsirate that exlended-dry conditions will prevail for some lime in the vicinity of waste packages.

Generally speaking, site conditions that are beneficial to a "cold" reposilory also benefit the performance of a "hot" repository. If we find that the bulk permeability is too small to promote significant buoyant, gas-phase flow and that hetcregeneity does not result in significant focusing of rapor flow and condensate drainage, it may be possible to demonstrate that a sub-boiling repository has a negligible impact on the ambient hydrological system. These same sile conditions are also beneficial for extending the period of above-boiling temperatures and, during that lime, minimizing the presence of mobile liquid water in the vicinity of waste packages.

\section{Numerical Models, Physical Data, and Assumptions}

\section{III.A V-TOUGH Hydrothermal Flow Code}

All hydrothermal ealeulations in this study were carried out using the V-TOUGH (vectorized transport of unsaluraled groundwater and heat) code. ${ }^{10} \mathrm{~V}$-TOUGH is Lawrence Livermore National Laboratory's enhanced version of the TOUGH code. which was developed at Lawrence Berkeley Laboratory by Pruess. "I V-TOUGH is a multidimensional numerical simulator capable of modeling the coupled transport of water, vapor, air, and heal in fractured porous media. Our models include boiling and condensation effects, the convection of latent and sensible heat, and thermal radiation.

\section{III.B Equivalent Continuum ModeJ}

Because of the impracticality of diseretely accounting for all of the fractures at Yucca Mountiin, it was necessary to account for fractures using the equivalent contintum model (ECM). The assumption of capillary pressure and thermal equilibrium between fractures and matrix allows the fracture and matrix properlies to be pore-volume-averaged into an equivalenı medium. The bulk porosity, $\phi_{\mathrm{h}}$, bulk saturation, $S_{\mathrm{h}}$, and bulk hydraulic conduclivity, $K_{\mathrm{h}}$, of the equivalent medium are given by:

$$
\begin{aligned}
& \phi_{\mathrm{h}}=\phi_{\mathrm{f}}+\left(1-\phi_{\mathrm{f}}\right) \phi_{\mathrm{m}} \\
& S_{\mathrm{b}}=\frac{S_{\mathrm{f}} \phi_{\mathrm{f}}+S_{\mathrm{m}}\left(1-\phi_{\mathrm{f}}\right) \phi_{\mathrm{m}}}{\phi_{\mathrm{f}}+\left(1-\phi_{\mathrm{r}}\right) \phi_{\mathrm{m}}} \\
& K_{\mathrm{h}}=K_{\mathrm{m}}\left(1-\phi_{\mathrm{f}}\right)+K_{\mathrm{f}} \phi_{\mathrm{f}}
\end{aligned}
$$

where $\phi_{m} \cdot S_{m} \cdot \phi_{l j}$, and $S_{\gamma}$ are the porosity and saturation of the matrix and fraclures, respectively, and $K_{\mathrm{m}}$ and $\boldsymbol{K}_{\mathrm{r}}$ are the hydraulic conductivities of the matrix and fractures. Because of the smal] $K_{\mathrm{m}}$ in the unsaturated zolic (UZ), $K_{\mathrm{h}}$ is almost completely dominated by $K_{\mathrm{\Gamma}}$ and $\phi_{f}$ for most fraeture spacings and permeabilities.

\section{III.C Thermo-Hydrological Properties}

All major hydrostratigraphic units in the UZ at Yucca Mountain are included in the models.2,12 The hyưrostratigraphic profile employed here has been used in previous modeling studies. $4,6-4,13$ The wit and dry thermal conductivily, $K_{\mathrm{th}}$, data were obtained from the Reference Information Basc (RIB). 14 In this study we use the RJB Version $+K_{\text {th }}$ values. We assume the steady-state liquid saluration profile oblained for a net recharge flux of $0 \mathrm{~mm} / \mathrm{yr}$, which yields a rcpository horizon saturation of $68 \% .13$

For the primary suite of calculations, a uniform fracture permeability is assumed. Because the bulk permeability, $k_{\mathrm{h}}$ is dominated by the fracture permeability, this assumption yiclds a $k_{\mathrm{h}}$ distribution that is searly uniform. The reference sase assumes a $k_{h}$ of 2.8 $\times 10^{-13} \mathrm{~m}^{2}$ (280 millidarcy), which is equivalent 10 three $100-\mu \mathrm{m}$ fractures per meter. We also considered the following values of $k_{\mathrm{h}}$ : I millidarcy (1hree $15-\mu \mathrm{m}$ fractures per meter), 10 millidarcy (three $33-\mu \mathrm{m}$ fractures per meter), 84 millidarey (threc $68-\mu \mathrm{m}$ 
fractures per incler), 1 darcy (three 15.3- $\mu$ in fractures per meler), 10 darey (threc $330-\mu \mathrm{m}$ fractures per meter). 40 darcy (onc $781-\mu \mathrm{m}$ fracture per meter), 84 darcy (one $1000-\mu \mathrm{m}$ fracture per meter), and 168 darcy (one $1260-\mu \mathrm{m}$ fracture por meler).

\section{III.D Initial and Boundary Conditions}

The vertical temperature, $T$, distribution in the models is initialized to correspond to the nominal genthermal gradient in the region. The atmonsphere at the ground surlace is nepresented by a coustant-property boundary, with $r$ and gas-phase pressurc, $p_{\mathrm{y}}$, fixed at $13^{\circ} \mathrm{C}$ and 0.86 atın. respectively. The relative humidity at the ground surfice is fixed so that it is in thermodynaınic equilibrium with the initial saturation conditions at the top of the TCw unit (the uppermost unit it our modets). Therefore, under initial (ambient) saturation and temperature conditions, there is no matss flux of waler vapor between the atrnnsphere and upper TCw.

We conducted our repository-scale calculations with an unsaiurated zone/saturated zone (UZ-SZ) model that explicitly includes hydrothermal flow in the upper $1000 \mathrm{~m}$ of the SZ. Conductive and convective hent flow, including buoyancy flow, are modeled in the SZ. Because the RIB ${ }^{\text {Ht }}$ lacks thermal property and hydrologic dala below the PPw unil (the lowermost unit in ous UZ moded). we assumed that the PPw dala were applicable to the upper $1000 \mathrm{~m}$ of the SZ (down to the lower boundary of the UZ-SZ model). The lower boundary of the UZ-SZ model has at constant temperature of $53.5^{\circ} \mathrm{C}$ and a fixed pressure corresponding to the liydrostalic pressure aud lemperature profile of the upper 1000 in of the SZ.

In some of the previnus work. ${ }^{6}$ it was assumed that because of the large fracture perme iability, buoyant convective mixing in the salurated zone (SZ) results in it acting as a heat sink. The large $k_{h}$ and storativily of the $S Z$ were also assumed to result in the waler table being at a fixed depth. For the drift-scale calculations reported here. we also assume that the water lable has a fixed depth $(\vdots=568.1 \mathrm{~m}$ ) and a constant temperature $\left(3 \mathrm{~J}^{\circ} \mathrm{C}\right)$. The constant-lemperature assumption causes the water lable to atel as a heat sink. Betause this model does not explicitly model hydrothermal flow in the SZ. it is called the "UZ" model. In comparing the UZ model with the UZ-SZ model, we found that. for the first 1000 yr, repository temperatures are insensilive to the treatment of heal flow at the water table. $7 .{ }^{7 .}$ Beciuse the primary use of the drift-scale model, which is described below, is to examine sub-repository-seale thenno-hydrological behavior during the first 1000 yr, the constinttemperature water table assumption does not significantly affecl the interpretation of our results. The initial temperature and saturalion at the repository horizon in both the UZ and UZ-SZ models are $23.5^{\circ} \mathrm{C}$ and $68 \%$, respectively.

\section{III.E Repusitory-Scale Mndels}

In conducting our modeling studies, we have reprosemed the repository al several different scales. The repository-scalc models assume radial symmetry about the ecnter of the reposilory and represent the repusitory as a disk-shaped heat snuree with a unifonnly distributed thermal load nuer the heated area of the repository. Becaluse of their radial symmetry, these models assume areally uniform thermo-hydrological propertics. Layered heterisgeteity (i.c. propurty uariability that oecurs in the vertical direction) can be represented by these models. We modeled repository arcas of $570,744,1139,1755$, and 2598 acres. For 6.,000 MTU of SNF, these repository areas correspond to AMLs of $110.5,83.4,55.3,35.9$, and 24.4 MTU/acre. For 22.5-yr-old SNF, these AMLs correspond approximalely to APDs of $114,86,57,37$, and 25 kW/acre, respectively. The repository-scalle models are well suited for representing mountain-scale behavior. such as mountaili-scale, buciyant, gas-phate convection. These models employ a relatively fine gridblock spacing at the outer perimeter of the repository to more accurately accoum for the effect of edge-cooling. We assume a Youngest Fuel First (YFF) SNF reccipt secnario with a 10yr cutoff for the youngest fuel. This scenario is referred to as $Y F F(10)$, We account for, in y'urly increments, the emplaced inventory of byiling water reactor (BWR) WPs. containing 40 nssemblics per WP. and pressurized water reactor (PWR) WPs, containing 21 assemblics per WP. The waste reccipt schedulle was delermined by King. ${ }^{\text {If }}$ For the 110.5-MTU/acre case, we considered the following values of $k_{\mathrm{h}}$ : I. 10,84, and 280 milliuarcy: and $1,10,40$, and 84 dircy. For the 24.4-, 35.9-, 55.3-, and 83,4-MTU/acre cases, we tonsidered $k_{\mathrm{b}}$ values of 280 millidarey and I, 10. 40. and 84 dircy.

\section{III.F Sub-Repository-Suale Models}

Becatse it areally atverages the thermal load. the repository-scale model cannot represent differentes in lemperature and saturation behavior within (I) the pillars, i.c.. the rock separitting neighboring emplacement drifts, (2) the emplacement drifis, or (3) the WPs themselves. The drift-scalc model is a two-dimensional cross-sectional mode' that explicitly represents the details of the WPs and emplatement drifts in the plane orthogonal to the drift axes. This rnodel is useful in representing details of thermohydrological behavior ill the drift (or suh-repository) scalc. We are interested in the detililed temperature distribution within and in the imenediate vicinity of the emplacement drifts. We are also interested in how sub-repository-seale. buoyant, gas-phas convection. which is driven by temperature differences between the drifis and pillirs. affects vapor and condensate flow and thermal performance. 
To take advantage of symmetry, the drift-scale model assumes an infinite repository with uniformly spaced emplacemenl drifts. The assurnption of an infinite repository area is applicable to the interior of the repository, which is not alfected by cooling at the edge. This region includes most of the repository area during at least the first $1000 \mathrm{yr}$. The drift-scule model represents a symmetry element from the symmetry plane down the center of the WP to the symmetry plane in) the pilliar between neighboring drifts. The thermal load is axially ancraged along the axis of the drift. The WP has a cross section of $1.6 \times 1.6 \mathrm{~m}$ and is located in the center of an emplacement drift that is $4.8 \mathrm{~m}$ high by $6.0 \mathrm{~m}$ wide. This drift tross section is reasunably representalive of a circular drift with it 7-m diameter. The drifts are assutned to remain open: therefore. heat flow from the WP surlace to the drift wall occurs as thermal radiation. convection, and conduction. This model can represent heterogencity that occurs at the stiale of the drifts.

The drifl-scale calculditions apply the $21-P W R / 40-$ BWR WP receipt scenario alssurned in the repositoryseale motels with one important distinction. Rather than blending all of the WPs received over the 23-yr emplacement period, we assumed a WP receipt scenario which is more realistic. We blended the heat output for the first 63 21-PWR WPs and 46 40-BWR WPs received during the first two years of reposilory operation. Calculations were done for center-to-center drift spacings of 99,66.8, 43.4, 28.8, and $21.7 \mathrm{~m}$ for AMLs of $24.2,25.9,55.3 .83 .4$, and $110.5 \mathrm{MTU} / \mathrm{acrc}$, respectively. In oróer to analyze the impact of sub-repositoryscale. busyiun, gats-phase convection, we esonsidered valucs of $k_{\mathrm{h}}$ of 10 and 280 millidarey, and 168 darey. For the $2 I-P W R$ and 40-BWR WP receipl secnario, a center-lo-tenter WP spating of $12 \mathrm{~m}$ was assumed. Note that these calculations are also applicable to a 12PWR/2I-BWR WP receipl scenario with a center-10center WP spacing of $6.86 \mathrm{~m}$.

\section{Discussion of Repository-Scale Modal Results}

\section{IV.A Thermo-Hydrological hehaviur}

With the use of the repository-scale model, we modeled 26 cases. including 5 AMLs and 8 different values of bulk permeability, $k_{\mathrm{t}}$. Table $]$ summarizes the thermal performance at two locations in the repository for all 26 cases. All cases were modeled for a minimum of 100.000 yr. Rither than presenting the vertical temperature and saturation profiles for all 26 cases, we examine the profiles in detail for the suite of 280 millidarcy cisses. In previous work, 4.8 we found that the threshold $k_{h}$ where mounlain-scale, bucoyant, gas-phase convection begins to dominate moisture movement is about I darey. Below this threshold, the effects of boiling tend to dominale the effects of buoyant, gasphase convection. We chose to focus on the $\mathbf{2 8 0}$ millidarey suite of cases, not because $\mathbf{2 8 0}$ millidarcy is considered to be the most likely value of $k_{h}$. but rather to more readily diseern the impact of boiling behavior on moisture movement without the competing influence of mountain-scalc, buoyun, gas-phase convection. A detailed examination of the impact of that convection on thermo-hydrological performance is presented in the following seclions.

Figure I shows the iemperalure and siluralion histories at varions locitions in the repository for the I 10.5-, 83.4-, and 55.3-MTU/atcre cases. Peak temperatures, $T_{\text {pe:ak, }}$ occur within the first $120 \mathrm{yr}$. In this report, we refer to radial location with respect to percentage of the repository area that it encloses. Therefore, a radial position of $0 \%$ corresponds to the repository eenter, while $100 \%$ corresponds to the outer perimeter. Notice that edge cooling effects do not penetrale to the inner $75 \%$ of the repository in the first $120 \mathrm{yr}$; consequently. $T_{\text {peak }}$ is about the same for the inner 75\% of the repository (Fig. 1a). For example, $T_{\text {peak }}$ is $187.2^{\circ} \mathrm{C}$ at the repository center and $186.0^{\circ} \mathrm{C}$ al the $75 \%$ radial position. Edec cooling reduces $T_{\text {peak }}$ for the outer $25 \%$ of the repository relative to the ecnter. At the outer edge of the reposilory, $T_{\text {peatk }}$ is only $112.4^{\circ} \mathrm{C}$. Edge cooling eventually penctrates into the center of the repository, reducing the duration of boiling, $/ \mathrm{hp}$, even ill the repository center.

Liquid saturation in the repository remains below ambient condilions long after boiling conditions have ceased for most of the reposilory. The inner $75 \%$ of the repository remains below ambient saturalion for at leas! 100,000 yr (Fig. Ib). The inner $99 \%$ of the repository remuins below ambient situration for at leitst $10,000 \mathrm{yr}$, while the outer $1 \%$ re-wets nearly back 10 ambent saturation within $5000 \mathrm{yr}$.

The vertical temperalure and saturation profiles are given for three different madial distanecs from the repository center (Figs. 2-4). The first value of $r(r=0 \mathrm{~m})$ corresponds to the center of the repository. The second value of $r$ corresponds w the radial position that encloses $50 \%$ of the repository. This position is representative of "average" conditions in the repository because half of the WPS are inside this radial position. The third value of $r$ corresponds to the radial position that encloses $95 \%$ of the repository and is a good representation of conditions at the repository edge (or perimeter) because only $5 \%$ of the WPs lic outside of this position.

Figure 2 shows the verticil temperature and saturation profiles for the 110 5-MTU/acre case at various times after amplacement. Notice that the thermal and dry-out perfor- 
mance is very similar for the 0 and $50 \%$ radial positions of the repository for the first thousand years and that edge cooling affects at leust the ouicr $5 \%$ of the repository. The flattening of the temperature profile at the nominai hoiling temperalure, $T_{\mathrm{h}}\left(=96^{\circ} \mathrm{C}\right)$. corresponds to two-phase flow effects, which result from condensale drainage. These effects are described in tnore detail in other reports. ${ }^{+-9}$ Dry-out duc to boiling results in a 200 to 300-m-1hick dry-out zone for the inner $50 \%$ of the repository. Edge cooling substantially reduces the vertical extent of dry-out. Temperatures at the outer edge of the repository drop below boiling at about 2000 yr (Fig, 1a), while the ecenter remainss above $T_{\mathrm{b}}$ for more than 7000 yr. Temperatures for the entire repository have declined to below $T_{\mathrm{b}}$ within 10.000 yr: however. a large zone of sub-ambient saturations persists long after that (Figs. 2b and c). The suter $5 \%$ of the repository rewets back to ambient saturation within $50.000 \mathrm{yr}$. while the center remains below ambient saturation for more than $100,000 \mathrm{yr}$ (Fig. Ia).

The temperature and liquid saturation historics for the 83.4-MTU/acre cuase (Fig. 3) are similar to those of the 110.5-MTU/acre ease. except that the duration of boiling and sub-ambient liquid saluration conditions is less (Figs. Ic and d). The inner $75 \%$ of the repository shows a similar $T_{\text {peik }}\left(146^{\circ} \mathrm{C}\right)$. At the outer edge. $T_{\text {ptak }}$ is only $97.8^{\circ} \mathrm{C}$.

\begin{tabular}{|c|c|c|c|c|c|c|c|c|c|c|c|}
\hline \multicolumn{12}{|c|}{$\begin{array}{l}\text { Table I } \\
\text { Averaged thermal performance at two locations in the repository }\end{array}$} \\
\hline \multicolumn{4}{|c|}{$\begin{array}{l}\text { Thermal loading conditions } \\
\text { and bulk permeability, } k_{\mathrm{h}}\end{array}$} & \multicolumn{4}{|c|}{$\begin{array}{l}\text { Center of } \\
\text { repository }\end{array}$} & \multicolumn{4}{|c|}{$\begin{array}{l}97 \% \text { radjal position } \\
\text { in the repository }\end{array}$} \\
\hline $\begin{array}{c}\text { AML } \\
\text { (MTU/acre) }\end{array}$ & $\begin{array}{c}\text { APD } \\
(k W / \text { acre })\end{array}$ & $\begin{array}{c}\text { Arca } \\
\text { (acres) }\end{array}$ & $\begin{array}{c}k_{h} \\
(\text { darey) }\end{array}$ & $\begin{array}{l}T_{10 i 10} \mathrm{yr} \\
\left({ }^{\circ} \mathrm{C}\right)\end{array}$ & $\begin{array}{l}T_{\text {pLak }} \\
\left({ }^{\circ} \mathrm{C}\right)\end{array}$ & $\begin{array}{c}t_{\text {peuk }} \\
(\mathrm{yr})\end{array}$ & $\operatorname{lop}_{(\mathrm{yr})}$ & $\begin{array}{l}T_{1(M)} \mathrm{yr} \\
\left({ }^{\circ} \mathrm{C}\right)\end{array}$ & $\begin{array}{l}T_{\text {peilk }} \\
\left({ }^{\circ} \mathrm{C}\right)\end{array}$ & $\begin{array}{l}t_{\text {puak }} \\
(\mathrm{yr})\end{array}$ & $\begin{array}{l}1 \mathrm{bp} \\
(\mathrm{yr})\end{array}$ \\
\hline 24.2 & 25 & 2598 & 0.28 & 62.9 & 65.7 & 145 & $\mathrm{NA}$ & 48.3 & 59.7 & 86 & $\mathrm{NA}$ \\
\hline 24.2 & 25 & 2598 & 10 & 63.0 & 65.7 & 145 & $\mathrm{NA}$ & 47.9 & 59.7 & 86 & NA \\
\hline 24.2 & 25 & 2598 & 40 & 63.1 & 65.7 & 145 & $\mathrm{NA}$ & 46.2 & 59.6 & 86 & $\mathrm{NA}$ \\
\hline 24.2 & 25 & 2598 & 84 & 61.6 & 65.7 & 145 & $\mathrm{NA}$ & 42.2 & 59.3 & 86 & NA \\
\hline 35.9 & 37 & 1755 & 0.28 & 81.6 & 85.8 & 143 & NA & 58.7 & 74.8 & 72 & NA \\
\hline 35.9 & 37 & 1755 & 1 & 81.6 & 85.8 & 143 & NA & 58.6 & 74.8 & 72 & NA \\
\hline 35.9 & 37. & 1755 & 10 & 82.0 & 85.9 & 143 & $\mathrm{NA}$ & 57.2 & $7+7$ & 72 & $\mathrm{NA}$ \\
\hline 35.9 & 37 & 1755 & 40 & 79.6 & 85.5 & 137 & $\mathrm{NA}$ & 50.3 & 74.0 & 72 & $\mathrm{NA}$ \\
\hline 35.9 & 37 & 1755 & 84 & 77.2 & 84.9 & 140 & $\mathrm{NA}$ & 45.8 & 72.6 & 69 & NA \\
\hline 55.3 & 57 & 11.39 & 0.28 & 105.1 & 108.8 & 122 & 2152 & 73.1 & 96.7 & 61 & 85 \\
\hline 55.3 & 57 & 1139 & 1 & 103.5 & 107.6 & 121 & 2092 & 73.1 & 96.4 & 60 & 60 \\
\hline 55.3 & 57 & 1139 & 10 & 100.0 & 105.1 & 100 & 1471 & 69.4 & 93.7 & 50 & 0 \\
\hline 55.3 & 57 & 1139 & 40 & $S 3.8$ & 103.6 & 81 & $76 ?$ & 59.2 & 89.4 & 61 & 0 \\
\hline 55.3 & 57 & 1139 & 84 & 89.4 & 102.3 & 80 & 403 & 54.7 & 86.8 & 50 & 0 \\
\hline 83.4 & 86 & 755 & 0.28 & 139.3 & 146.0 & 181 & 5086 & 95.8 & 118.3 & 60 & 991 \\
\hline 83.4 & 86 & 755 & 1 & 135.9 & 144.9 & 180 & 4811 & 92.8 & 117.4 & 61 & 814 \\
\hline 83.4 & 86 & 755 & 10 & 128.0 & 134.6 & 121 & +171 & 81.7 & 1120 & 60 & 328 \\
\hline 83.4 & 86 & 755 & 40 & 123.3 & 132.2 & 100 & 3724 & 73.8 & 110.4 & 60 & 189 \\
\hline 83.4 & 86 & 755 & 84 & 119.6 & 130.4 & 100 & 2917 & 68.6 & 108.7 & 60 & 150 \\
\hline 110.5 & 114 & 570 & 0.001 & 183.4 & 197.5 & 100 & 7988 & 116.4 & 153.2 & 60 & 2272 \\
\hline 110.5 & 114 & 570 & 0.01 & 178.1 & 190.4 & 120 & 8091 & 114.0 & 148.1 & 60 & 2248 \\
\hline 110.5 & 114 & 570 & 0.28 & 175.8 & 187.2 & 121 & 8105 & 112.4 & 144.0 & 60 & 2150 \\
\hline 110.5 & 114 & 570 & 1 & 176.3 & 186.3 & 121 & 8125 & 108.7 & 1420 & 60 & 1814 \\
\hline 110.5 & 114 & 570 & 10 & 162.2 & 170.9 & 120 & 7997 & 97.1 & 131.6 & 50 & 1060 \\
\hline 110.5 & 114 & 570 & 40 & 159.2 & 170.2 & 402 & 7743 & 89.2 & 132.3 & 61 & 721 \\
\hline 110.5 & 114 & 570 & 84 & 156.5 & 169.8 & 202 & 6790 & 83.7 & 132.3 & 60 & 548 \\
\hline
\end{tabular}


Most of the repositon re-wets back to ambient saluration within 100,000 y. Edge cooling cuuses the outer $1 \%$ of the repnsilory to never undergo signifücant dry-out (Fig. Id).

Figure 4 shows the vertical temperalure and saturation profiles for the 55.3-MTU/acre tiase. Notice that the thermal and dry-out performunce is similar to that of the 83.4-MTU/acre case exeept that the vertical extent of hoiling and dy-out cfects is substantially less. Morever, the duration of boiling and sub-ambient liquid saturation conditions is substantially less for the 55.3-MTU/acre case

Figure 1. Temperature history (a) and licuid situration history (b) at vatrinus repository locations relative to the reposilory center for an AML of I 10.5 MTU/acre. Also plolted are temperature history (c) and liquid saturation history (d) for an AML of 83.4 MTU/tace, and temperature history (c) and licuid saturation history (f) for an AML of 55.3 MTU/acre. The locations are identified as the persentage of the repository area enclosed, with 0\% corresponding to the repository center, and $100 \%$ corresponding to the outer perimeter of the repository. Note different lemperature and time seales.

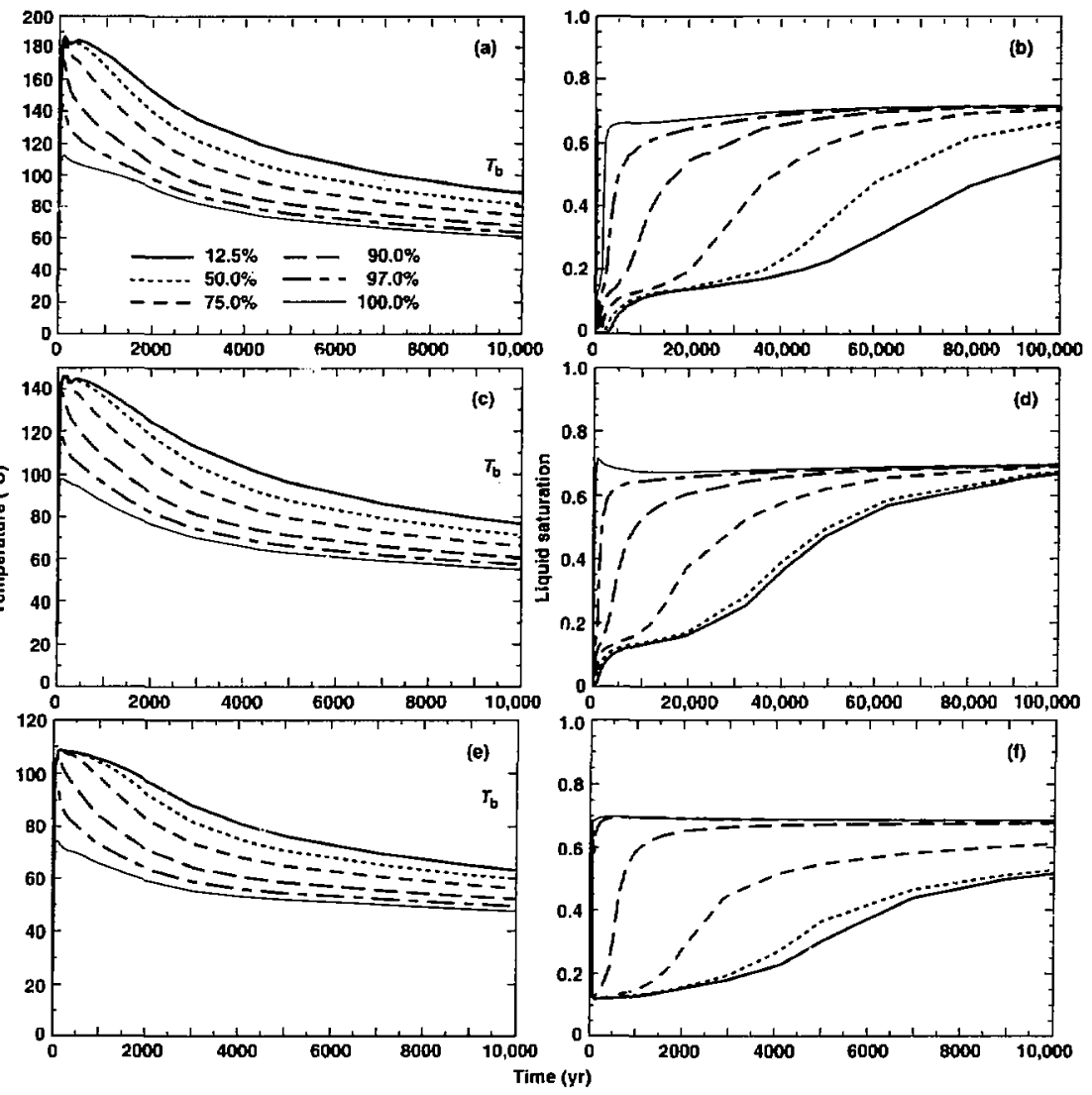


(Figs. Ic and $f$ ) than for the 83.4-MTU/acre case (Figs, is and d). Temperatures in the outer $3 \%$ of the reposifory never exceed $T_{\mathrm{h}}$, and $T_{\text {ncak }}$ at the outer edge is only $74.7^{\circ} \mathrm{C}$. Liquid saturations for the inner half of the repository re-swe hack to ambicnt conditions in about 30,000 yr. Between the 50 atnd $75 \%$ radial posilions. liquid saturations re-wet back in ambient conditions in aboul $20.000 \mathrm{yr}$. Re-wetting takes about $10.000 \mathrm{yr}$ at the $84 \%$ rildial position, 2000 yr at the $90 \%$ position, and 700 yr at the $94 \%$ position. Al the $97 \%$ ridial position; re-wetting takes about $150 \mathrm{yr}$, and dry-out never oxicurs for the euter $3 \%$ of the repository.

Figure 5 shows the emperature history lor the 35.9- and 24.2-MTU/acre cases. respeclively. Because of the large repusitory ureas, tooling effects do not penelrate as far inlo the repository. Conseyuently, $T_{\text {peak }}$ is about the same for the inner $90 \%$ of the repository (Figs. 5a and b). For the inner 50\%, the entire temperature history is very similar. For the 35.9- and 24.2MTU/acre cases. $T_{\text {puak }}$ is 85.8 and $65.7^{\circ} \mathrm{C}$. respectively.

Figure 2. Vertical temperature profiles at various radial distances, $r$, from the repository centerline for an AML of 110.5 MTU/acre at (a) $t=1000 \mathrm{y} r$, (b) $t=10,000 \mathrm{yr}$, and (c) $t=36,000 \mathrm{yr}$. Note different lamperature scaltes. Vertical lic|uid saturation profiles are also plotled at (d) $t=1000 \mathrm{yr}$. (c) $t=10.000 \mathrm{yr}$. and $(\mathrm{C}) t=36,000 \mathrm{yr}$.
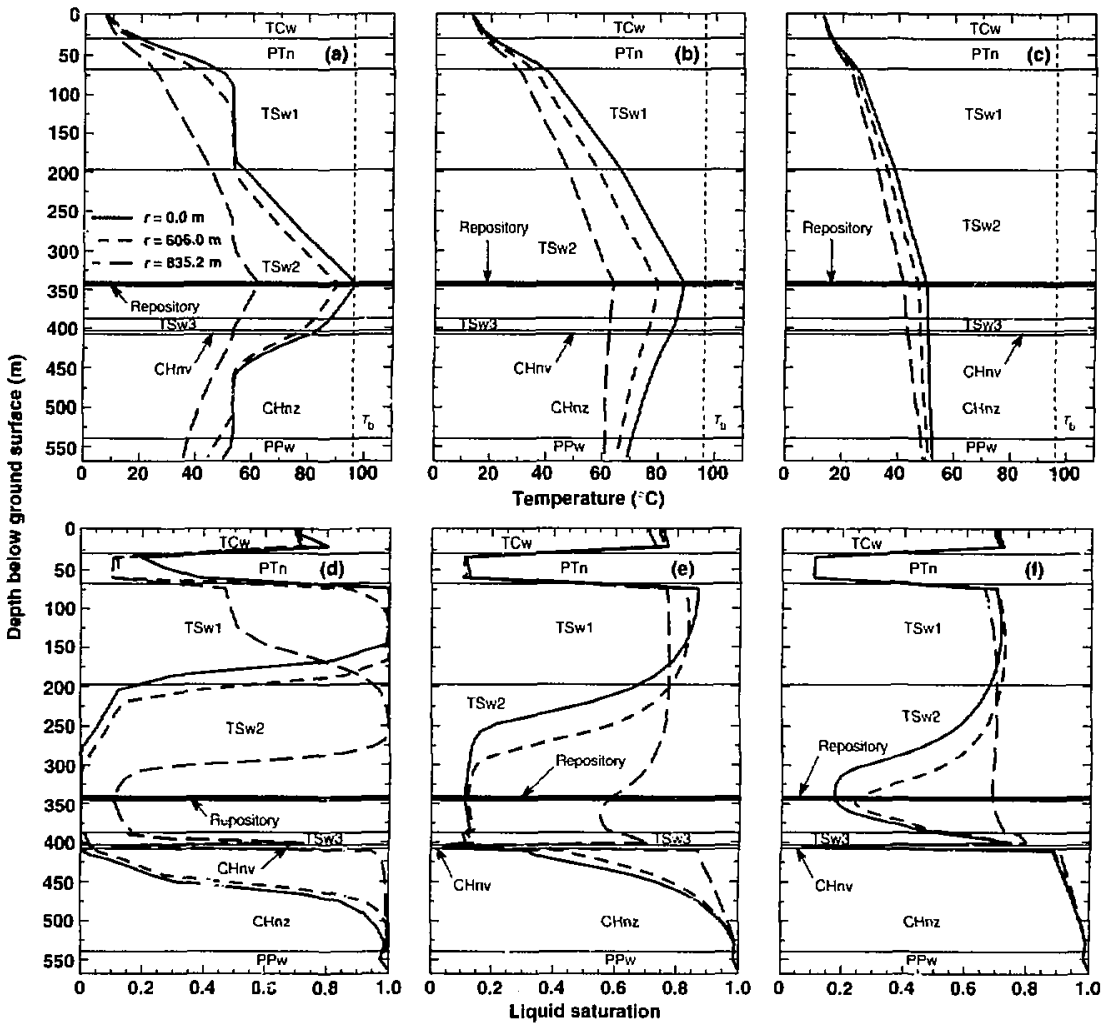
Edge cooling reduees $T_{\text {prik }}$ for the outer $10 \%$ of the

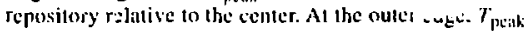
is 58.2 and $+7.8^{\circ} \mathrm{C}$ for the 35.9. and 24.2-MTU/aere cises, respectively:

Figure 6 show's the vertical temperilure profils: for the 35.9-and 24.2-MTU/acre cases. Fotice that the repository-scale model does not predict lemperatures to cxceed $7_{\mathrm{h}}$. indicating that areraged temperature conditìns throughout the repository rem:itn below bojling. However, as will be discussed later local temperalures around the emplac new drift may be well atove boiling for WPs contatioing a large number of SNF assemblies. Because of the absence of boiling anditions in the repositot i'-scale model, and because 280 millidarcy is below the threshold where mountan-scale, bucyamt. g-us-phase contection results in significant moist ure tnovement, the 2.1.2- and 35.9-MTU/acic cases sl:ow a miner change ira saturation relative w almbient conditions. Therefore. we did not provide the verticil satura: son , irofiles for these mo a asts.

Figure 3. Verticul temerature profiles al various radial distames, $r$. from the repository ceinterline for an AML of 33,4 MTL/alere ill (a) $t=1000 \mathrm{yr},(\mathrm{b}) t=10,000 \mathrm{yr}$, and $(c) t=33,000 \mathrm{yr}$. Nole different temperature stiles. Vertical liquid staturation profiles are also ploled at $(d) t=1000 \mathrm{yr}$, (c) $t=10,000 \mathrm{yr}$, and $(f) t=3,3,009 \mathrm{yr}$.
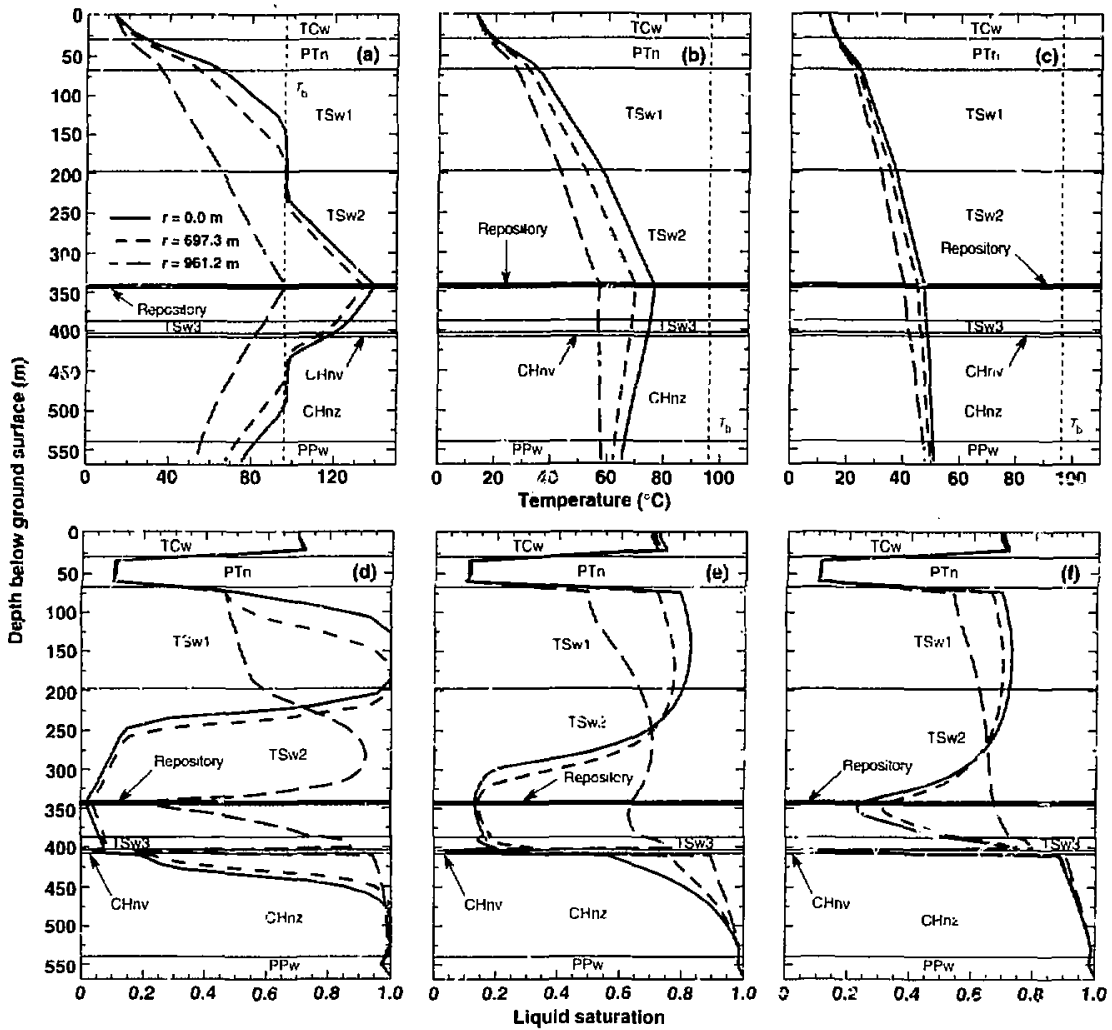
As in past studies. ${ }^{+. x}$ when analyzing dry-out and rewetting behavior. we use the term. nomalized liquid saturation. $\bar{S}_{1}$, which is given by

$$
\bar{s}_{1}=\frac{s_{1}}{s_{\text {l.inil }}}
$$

where $S_{1}$ is the current liquid saturation and $S_{1, \text { inil }}$ is the initial (or ambient) liquid saturation. To compare the rewetting behavior of vatious AMLs, we compared the duration of time that $S_{1}$ in the repository is below $90 \%$ of ambient (Fig. 7 ) as a function of repositury location. Because $\bar{S}_{1}=0.9$ when $S_{1}$ has been restored to $90 \%$ of ambient. we tull this time $t\left(\bar{S}_{l}=0.9\right)$. For the inner $12.5 \%$ of the repository, $t\left(\bar{S}_{1}=0.9\right)$ is 118.413 and 77.290 yr for 110.5 and 83.4 MTU/acre, respectively. For the inner $50 \%$ of the 55.3MTU/acre repository. $n\left(\bar{S}_{1}=0.9\right.$ ) is 22.150 yr.

Edge cooling substantially reduces $r\left(\bar{S}_{1}=0.9\right)$ for the outer repository area (Fig. 7). The impact of edge cooling on $r\left(\bar{S}_{1}=0.9\right)$ at the repository edge increases

Figure 4. Vertical temperature profiles at vilrious radial distances, $r$, from the repository centerline for an AML of 55.3 MTU/acre al (a) $t=1000$ yr. (h) $t=10.000 \mathrm{yr}$. and (c) $t=36.000$ yr. Verticial liquid saluration profiles are also plotted al (d) $t=1000$ yr. (c) $t=10,000 \mathrm{yr}$, and $(s) t=36,000 \mathrm{yr}$.
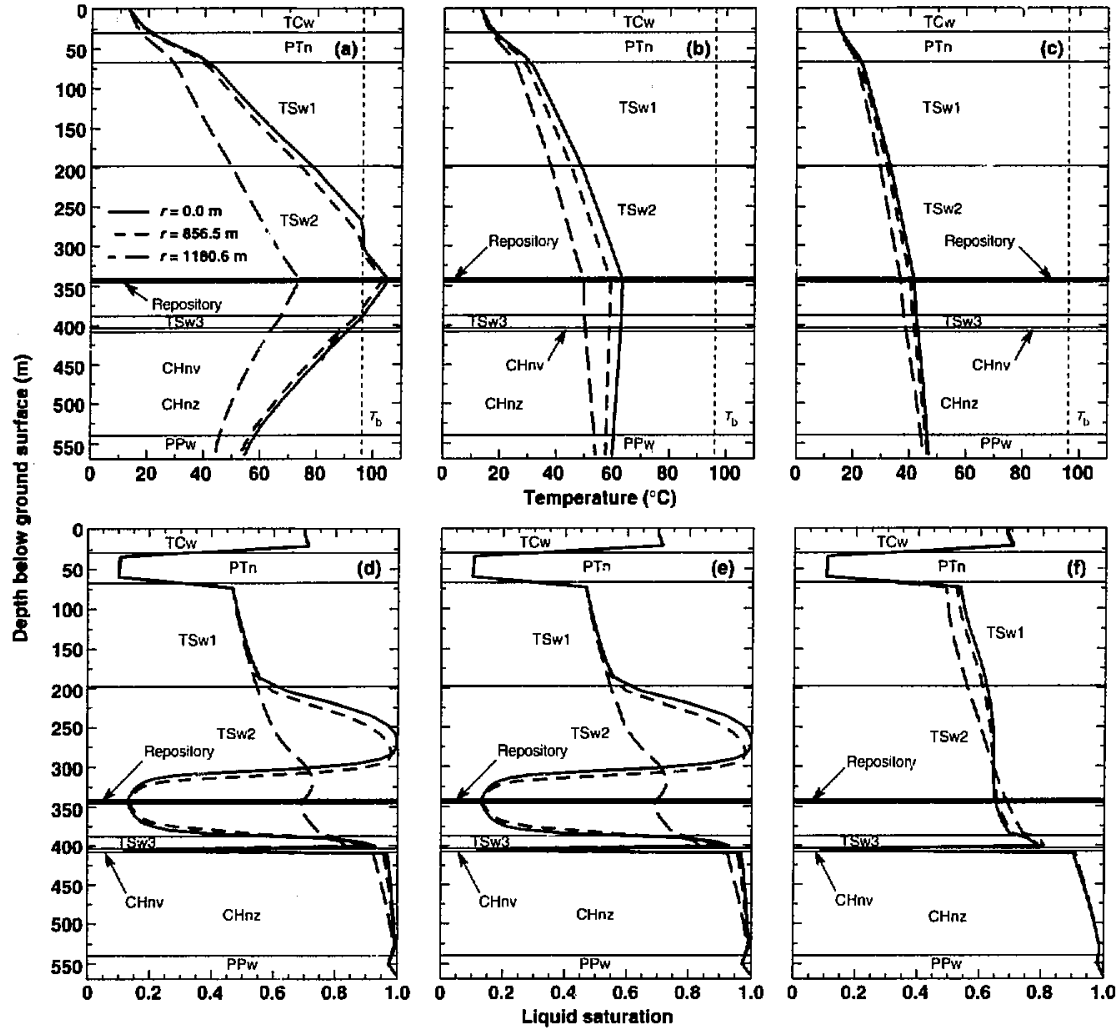
with decreasing AML. At the $90 \%$ repository location, $t\left(\bar{S}_{\mathrm{I}}=0.9\right)$ is 30 ú.339. 20.442, and $1172 \mathrm{yr}$ for AMLs of $110.5,83.4$, and 55.3 MTU/acre, respectively. For 55.3 MTU/atre, ary-out never occurs for the cutcr $3 \%$ of the reposilory. Al the outcr edge (100\% reposilory lotiltiou), $/\left(\bar{S}_{1}=0.9\right.$ ) is 1996 and 289 yr for 110.5 and 83.4 MTU/acre. respectively. We also calculated the areaweighted $r\left(\bar{S}_{1}=0.9\right)$. which we eull $i\left(\bar{S}_{1}=0.9\right)$. This is effectively equivalent to $n\left(\bar{S}_{1}=0.9\right)$ for an "average" WP in the repository. For AMLs of I 10.5, 83.4, and 55.3 MTU/acre, $f\left(\bar{S}_{1}=0.9\right)$ is $71.712,57.414$, and 14,929 yr, respectively.

Figure 8 shows the duration of the boiling period, $t_{\mathrm{hp}}$ as a function of radial position for the 110.5-, 83.4-. and 55.3-MTU/acre cases and all of the values of $k_{h}$ considered. The influcnce of edge cooling is evident. Nolice the effet that increasing $k_{h}$ has on decreasing

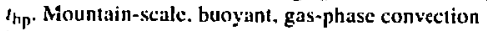
begins to significantly cool repository temperatures for $k_{k}>1$ darey. For $k_{k} \leq 1$ darcy, $\bar{t}_{\text {br }}$ is insensitive to $k_{b}$.

Figure 5. Temperature history at various repositury localions for an AML of (a) $35.9 \mathrm{MTU} / \mathrm{acrc}$, and (b) 24.2 MTU/acre. The locations are identified as the percentage of the repensitery area enclosed, with $0 \%$ corresponding 10 the repository eenter, and $100 \%$ corresponding to the outer perimeter.

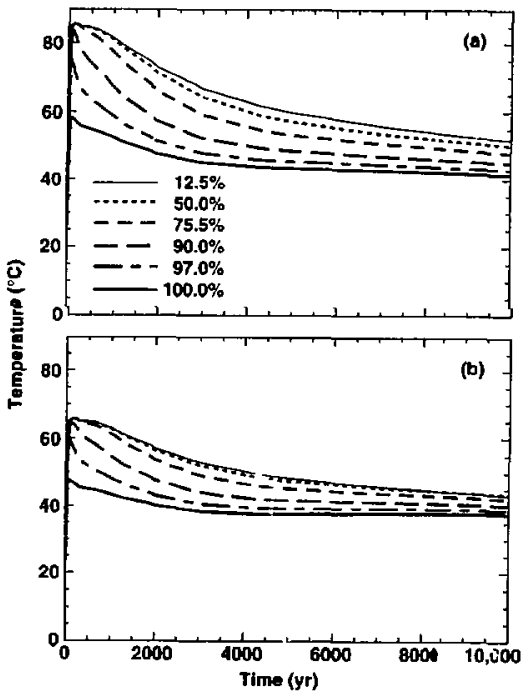

Notice that the sensitivity of $t_{b,}$ to $k_{b}$ increases with decreasing AML.

Figure 9 shows the area-weighted boiling perind duration. $i_{h p}$, for various $k_{h}$ values as a function of AML. For the 280-millidarcy cascs. $\bar{t}_{\text {thp }}$ is 5446.339l. and 1424 $y r$ for $A M L s$ of 110.5 .83 .4 , and 55.j MTU/acre, respextively. The cooling effect that mountain-scalc, buoyant. gas-phase convection has on $\bar{i}_{\mathrm{hp}}$ intreases with decreasing AML. Accordingly, the $110.5-M T U /$ ace cuse is least sensitive to this effect. For the 110.5-MTU/acre, I-darcy casc, this cooling effect reduces $\bar{T}_{\mathrm{hp}}$ by $2.9 \%$ relative to the 280-millidarcy case, while for 83.4 and $55.3 \mathrm{MTU} / \mathrm{acrc}$, $\bar{i}_{\mathrm{h} p}$ is reduced by 8.3 and $4.3 \%$, respeclively. For the 110.5 -MTU/acre, 10-darcy casc. $\bar{t}_{\mathrm{hp}}$ is reduced by $17.5 \%$ relative to the 280 -millidarcy case, while for 83.4 and 55.3 MTU/acre. the reduction is 29.2 and $34.9 \%$, respectively. For the 110.5-MTU/acre, 40-darcy casc, $\bar{i}_{\mathrm{bp}}$ is reduced by $28.6 \%$ relative to the 280 -millidarcy case, while for 83.4 and $55.3 \mathrm{MTU} / \mathrm{acre}$. the reduction is 39.4 and $73.7 \%$. respectively. For the 1105-MTU/acre, 84-darcy ease, $\bar{i}_{\text {rop }}$ is reduced by $40.7 \%$ relaljuc to the 280 -millidarcy tase, while for 83.4 and $55.3 \mathrm{MTU} / \mathrm{ac}$ re, the reduction is 53.1 and $88.5 \%$, respectively.

\section{IV.B Mountain-Scale Moisture Redistribution}

We compared the net buildup of liepuid water above the repository. $\Delta V_{1}$. for all of the thermal loids and $k_{h}$ cases (Fig. 9). For the high-k $k_{b}$. high-AML cases (10, 40 , and 84 dancy; 83.4 and 110.5 MTU/acre), a very carly peak in $\Delta V_{1}$ oceurs at 500 to $800 \mathrm{yr}$ (Figs. $9 \mathrm{c}-\mathrm{c}$ ). coinciding with the maximum exlent of boiling tondilions. After

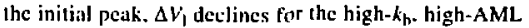
cases, with a trough occurring at $3000 \mathrm{yr}$, coinciding with the maximum vertical extent of dry-out. For 110.5 MTU/acre, $\Delta V_{1}$ declines to beldw zero (Figs. 9d and e). For 83.4 MTU/acre, the trough is less pronounced as $\Delta V_{1}$ stays well above zero (Figs. 9c-c). After the trough oecurs in the 83.4- and $110.5-\mathrm{MTU} / \mathrm{ace}$ cases, the increase in $\Delta V_{1}$ resumes until a second peak in $\Delta V_{1}$ oceurs al around 20.000 to $30,000 \mathrm{yr}$. For the 55.3MTU/acre case, there is no trough, and the increase in $\Delta v_{1}$ is uninterrupted (Figs. 9a-t). For 10, 40. and 84 darcy, the 55.3-, 83.4- and 110.5-MTU/acre cases undergo the same initial rale of increase in $\Delta v_{1}$ until 500 yr. when the 110.5-MTU/acre case reaches its initial peak, and $800 \mathrm{yr}$, when tine 83.4-MTU/acre case reaches its initial peak (Figs, $10 \mathrm{c}-\mathrm{c}$ ). This initial peak is related to the interaction of the heat-pipe effect and mountainscalc, buoyant, gas-phase convection.

It is important to note that $\Delta V_{1}$ is always greater in the 55.3- and 83.4-MTU/acre cases than in the I10. $M T U / a c r e$ case. We plot the maximum $\Delta V_{1}$ (called $\Delta v_{\mathrm{l}}^{\text {nlax }}$ ) for all of the AMLs and yalues of $k_{\mathrm{h}}$ considered 
(Fig. 90). For 55.3 MTU/acre, $\Delta v^{\text {mlux }}$ is 1.5. 1.3. 2.4. 2.6. and 2.5 times grealer than in the 110.5 -MTU/acre case for $\mathbf{2 8 0}$ millidarcy and $\mathrm{I}, 10,40$, and 84 darcy, respectively. For $83.4 \mathrm{MTU}$ /acre. $\Delta v_{1}^{\max }$ is 1.5 .1 .7 . $1.4,1.4$, and 1.5 limes greater than in the $110.5-\mathrm{MTU} /$ acre case for 280 mill idarcy and I, 10, 40, and 84 darcy, respectively. To the first order. for intermediate in high AMLs, $\Delta v_{i}^{\max }$ is proportional to the repository area. For the 110.5-MTU/acre case and $k_{h}<10$ millidarcy, $\Delta V_{1}$ is always negative (i.c., there is a net decrease in liquid saturation). Consequently, if the large-scale connected $k_{h}$ is small enough, mounlain-scale, buoyant. gas-phase convection does not result in a liquid water buildup above the repository.

For 280 millidarcy, $\Delta v_{i}^{\text {max }}$ for 24.4 and 35.9 MTU/acre is 26 and $34 \%$ of $\Delta V_{\text {int }}^{\text {nit }}$ for the 110.5 MTU/acre case; however, $\Delta V_{i}^{\text {max }}$ for the latter case is relatively small to begin with. For l0 darcy. $\Delta v_{1}^{\text {ntax }}$ for 24.4 and $35.9 \mathrm{MTU} / \mathrm{acc}$ is 50 and $105 \%$ of $\Delta v^{\text {mix }}$ for the 110.5-MTU/acre casc. For 40 darcy, $\Delta V_{1}^{\text {nia }}$ for 24.4 and $35.9 \mathrm{MTU} / \mathrm{acre}$ is 1.7 and 2.9 times greater

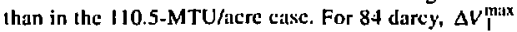

Figure 6. Vertical temperature profiles at various radial distances, $r$, from the repository centerline for an AML of 35.9 MTU/ acre at (a) $t=1000 \mathrm{yr}$, (b) $t=10,000 \mathrm{yr}$, and (c) $t=32,000$ yr. Vertical temperature profiles for an AML of 24.2 MTU/acre are also plotted at (d) $t=1000 \mathrm{yr}$, (c) $t=10.000 \mathrm{yr}$, and $(f) t=30,000 \mathrm{yr}$. Note rifferent temperature scales.

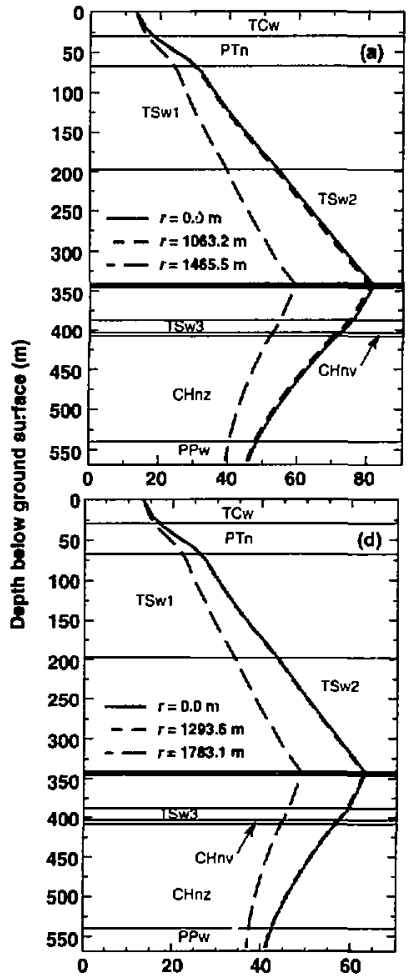

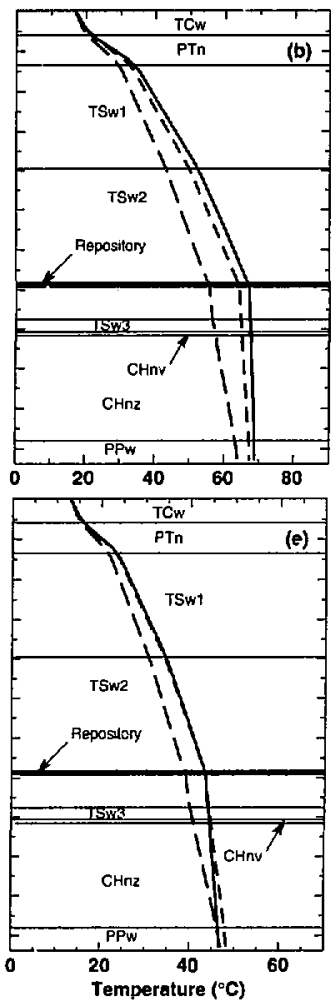

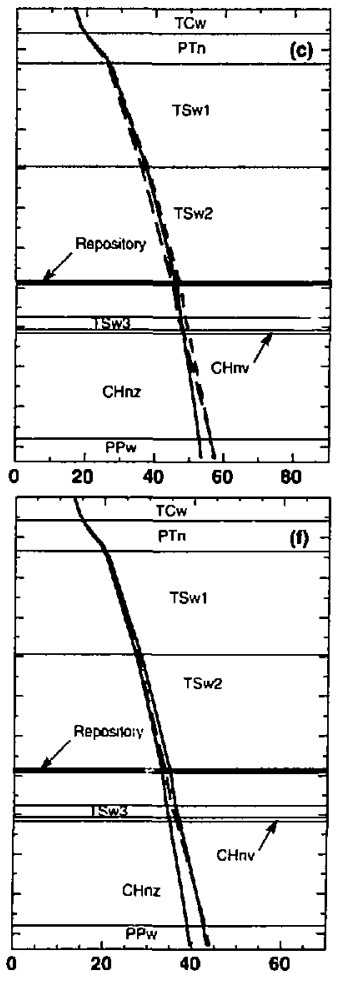




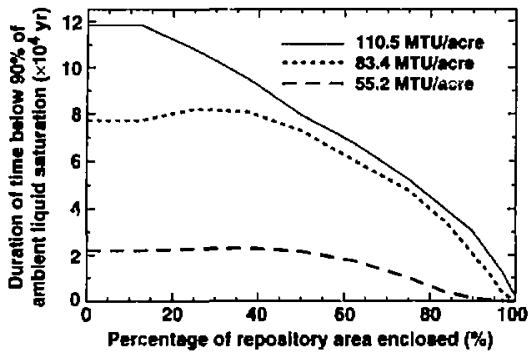

Figure 7. Durstion of timc during which liquid saturation al various reposilory localions is below $90 \%$ of the ambient value. for $k_{\mathrm{b}}=\mathbf{2 8 0}$ millidarcy and various AMLs. The lacations are identificd as the percentage of the repository area enclosed, with $0 \%$ corresponding to the repository cemter, and low\% corresponding to the outer perimeter. for 24.4 and $35.9 \mathrm{MTU} / \mathrm{acre}$ is 2.8 and 3.4 times greater than in the 110.5-MTU/acre case. Therefore. for low $k_{\mathrm{h}}\left(k_{\mathrm{h}}<1\right.$ darcy $)$, the low-AML cases result in less net liquid water buildup than the high-AML eases, while for high $k_{\mathrm{h}}\left(k_{\mathrm{h}}>40\right.$ darcy). $\Delta V_{\mathrm{l}}^{\text {maix }}$ is proportional to the repository area.

It is important to note that because the ECM cannol represent nonequilibrium fracture-matrix flow, it underprediets the condensate drainage flux and. consequently, overpredicts $\Delta V_{1}$. However, $\Delta V_{1}$ is a useful indicator (or surrogatc) of the overall magnitude of condensatc drainage flux and saturation buildup effects. The slope of the $\Delta V_{1}$ vs / curve is indicalive of the overall rale of condensare generation that arises from mountain-scale, buoyant vapor now. For high AMLs, it is indicative of the competition belween vapor flow driven by the gus-pressuse buildup due to boiling. and vapor flow driven by thermal buoyancy.

It is also important to point out that the purpose of this study is to illustratc the general sensitivity of largescale thermo-hydrological behavior to a wide range of

Figure 8. Duration of the bniling period at various reposilory locations for AMLs of (a) 110.5 , (b) 83.4. and (c) 55.3 MTU/acre. The locations are identified as the percentage of the repository arca enclosed. with 0\% corresponding to the repository center, and 100\% corresponding to the outer perimeter. (d) Area-weighted Juration of the boiling period as a function of AML.
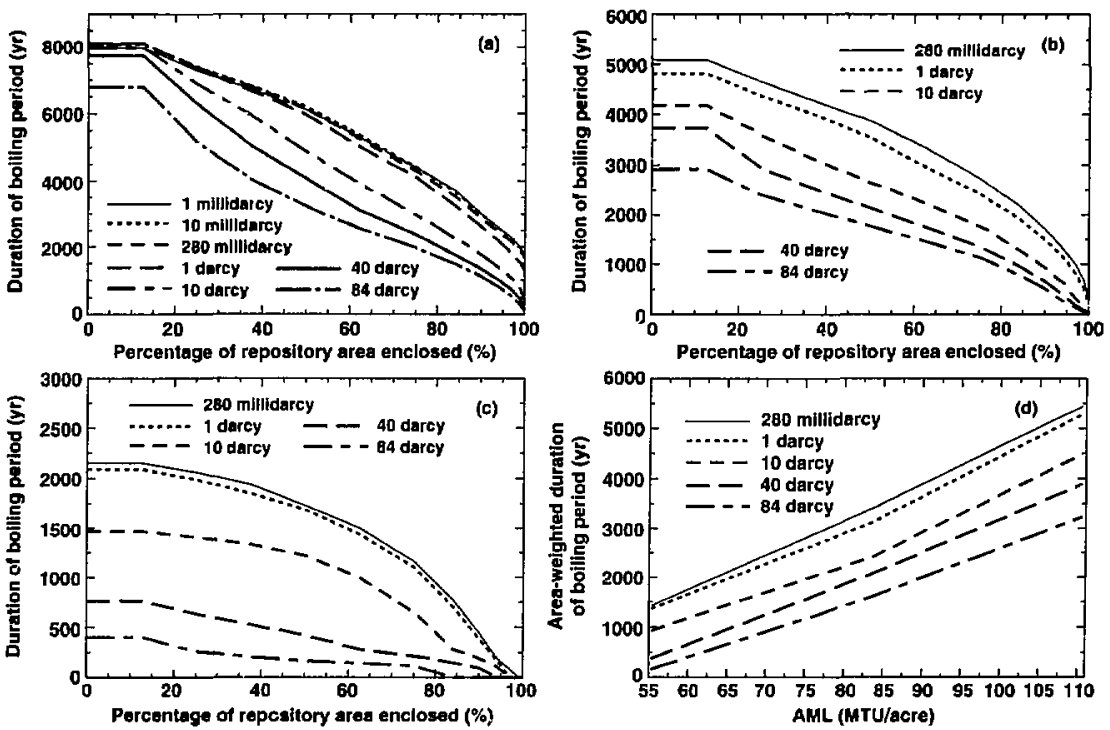
conditions through the use of macroscopic parametcrs such as $t_{\mathrm{h},}, \Delta V_{1}$, and $\Delta V^{\max }$. Any attempt to make specific inferences of this behavior on wastc package performancc and radionuclide transport would require a far more detailed look at the spatial distribution of the repository-heatdriven changes to temperatures, liquid saturations, and vapor and liquid nuxes than can be addressed in this report.
It is likely that the $k_{h}$ distribution at Yucca Mountain will be highly variable. Somc of that variability will be random, while some may be correlated with discrete hydrological features like fault zones or hydrostratigraphic units such as the nonwelded vitric tuff units (PTn and CHnv). According to Wecks, ${ }^{16.17}$ in at least some portions of the repository horizon in the TSw2, $k_{b}$ may be on the

Figure 9. Net buildup of liquid waler above the repository vs time for various AMLs and $k_{\mathrm{h}}$ values of (a) 280 millidarcy and (b) 1 , (c) 10 , (d) 40 , and (c) 84 darcy. (f) Maximum net buildup of liquid water above the repository as a funclion of AML for various values of $k_{\mathrm{p}}$.
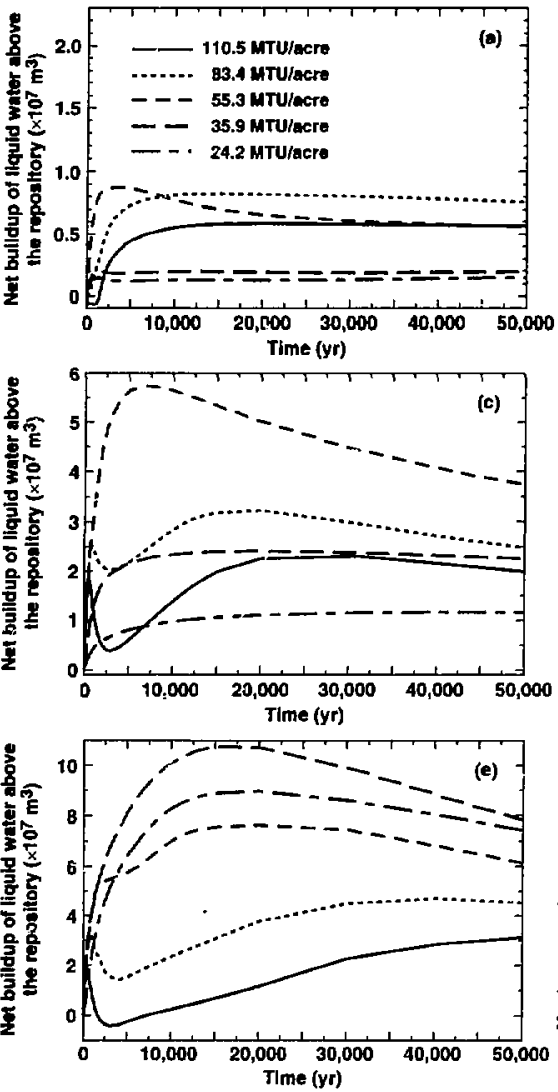
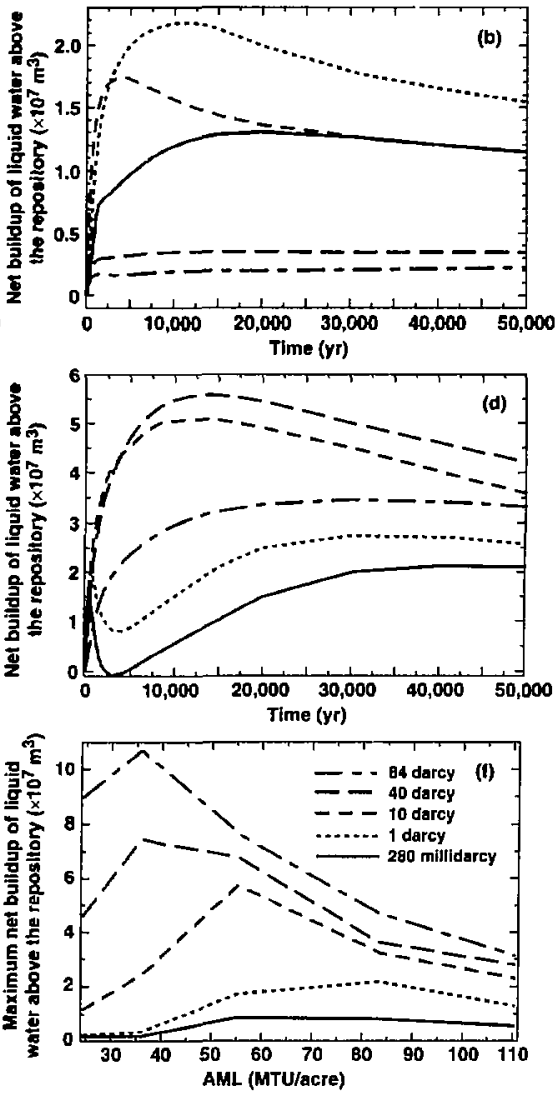
order of 200 darcy, while in other units such as the PTn, CHnv, and CH11\%, il is much smaller ( $k_{h}<1$ darcy). As in other studies, ${ }^{4 . x .4}$ this study considered a very wide range of $k_{\mathrm{b}}$ in order to identify where distinct changes in thermohydrological behavior occur. These sensitivity analyses are needed to assist in the development of a robust site characterization and lesting program that will obtain the requisite data for establishing repository performance.

It should be pointed out that this sensitivily study of mountain-seale moisture movement was done for the idealized situation of a uniform $k_{h}$ distribution. Ref. 9 considers the situation in which the $k_{\mathrm{b}}$ distribution varies vertically, which results in a layered heterogeneous $k_{\mathrm{b}}$ distribution. That study found that a reduction in $k_{\mathrm{b}}$ over relatively narrow depth intervals can substantially influence mountain-scale moisture movement.

\section{Discussion of Sub-Repository-Scale Mcdel Results}

\section{V.A Temperature History in the Vicinity of the Emplacement Drif}

The preceding antalysis represents averaged thermohydrological hehavior in the repository. To investigale the details of behavior in the vicinity of WPs, it is necessary to use sub-repository-scale (or drifl-scule) models. Using the drift-seale model, we conducted calculations for AMLs of 24.2, 35.9, 55.3. 83.4. and I 10.5 MTU/acre. In order to analyze the impact of sub-repository-scale, buoyant, gasphase convection, we considered values of $k_{h}$ of 10 and 280 millidarey, and I 68 darcy. Table II summarizes the thermal performanee on the waste package (WP) surface and in the rock $0.75 \mathrm{~m}$ above the drift ceiling for all of the cases considered. Our earlier drifi-scale calculations, ${ }^{3}$ which blended 23 yr of WPs reeeived by the repository. resulted in peak WP temperatures occurring at $t_{\text {ptik }}=125$ yr. In those culctulations, the heat output from an individual WP is ramped up in the same fashion as in the repository-scale model rather than being irstantancously raised to the full-power equivalent of an individual WP. Using the WP receipt sebedule that more realistically accounts for local heating conditions, the drift-scalc models in this study predict $12<t_{\text {peak }}<70$ yr (Table II).

A critical issue to address in anulyzing the thermohydrological performarec in the vicinily of the emplacement drifts is the potential for sub-repusitoryscale, buoyant, gas-phase eonvection, which can occur within fracture nelworks having a conneclivily with

\begin{tabular}{|c|c|c|c|c|c|c|c|c|c|c|c|}
\hline \multicolumn{12}{|c|}{$\begin{array}{l}\text { Table II } \\
\text { Thermal performance for 21-PWR WPs and 40-BWR WPs with 12-m } \\
\text { center-to-center spacing between WPs; also applicable to 12-PWR } \\
\text { WPs and 21-BWR WPs with 6.86-m center-to-center WP spacing }\end{array}$} \\
\hline \multicolumn{4}{|c|}{$\begin{array}{l}\text { Thermal loading conditions } \\
\text { and bulk permeability, } k_{h}\end{array}$} & \multicolumn{4}{|c|}{$\begin{array}{l}\text { Waste package } \\
\text { surface }\end{array}$} & \multicolumn{4}{|c|}{$\begin{array}{l}0.75 \mathrm{~m} \text { above the drift } \\
\text { ceiling in the rock }\end{array}$} \\
\hline $\begin{array}{c}\text { AML } \\
\text { (MTU/acre) }\end{array}$ & $\begin{array}{l}\text { APD D } \\
(W / \text { /acre })\end{array}$ & $\begin{array}{l}\text { ift spacing } \\
\text { (m) }\end{array}$ & $\begin{array}{c}k_{\mathrm{h}} \\
\text { (darcy) }\end{array}$ & $\begin{array}{l}T_{1000 \mathrm{yr}} \\
\left({ }^{\circ} \mathrm{C}\right)\end{array}$ & $\begin{array}{l}T_{\text {Puilk }} \\
\left({ }^{\circ} \mathrm{C}\right)\end{array}$ & $\begin{array}{l}r_{\text {puak }} \\
\text { (yr) }\end{array}$ & $\begin{array}{l}t_{\mathrm{bp}} \\
(y \mathrm{r})\end{array}$ & 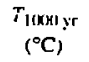 & $\begin{array}{l}T_{\text {puik }} \\
\left({ }^{\circ} \mathrm{C}\right)\end{array}$ & $\begin{array}{l}t_{p=u k} \\
(y r)\end{array}$ & $t_{\mathrm{hp}}$ \\
\hline 24.2 & 25 & 99.0 & 0.01 & 80.0 & 171.8 & 12.6 & 350 & 76.2 & 144.1 & 14.4 & 202 \\
\hline 24.2 & 25 & 99.0 & 0.28 & 79.4 & 170.4 & 12.8 & 310 & 75.8 & 142.2 & 17.6 & 195 \\
\hline 24.2 & 25 & 99.0 & 168 & 79.0 & 164.0 & 12.5 & 300 & 75.4 & 133.0 & 14.5 & 183 \\
\hline 35.9 & 37 & 66.8 & 0.01 & 99.3 & 172.5 & 14.1 & 1155 & 96.3 & 146.1 & 19.3 & 1014 \\
\hline 35.9 & 37 & 66.8 & 0.28 & 99.2 & 170.7 & 12.4 & 1148 & 96.2 & 144.4 & 25.2 & 1010 \\
\hline 35.9 & 37 & 66.8 & 168 & 97.7 & 165.2 & 12.8 & 1111 & 94.9 & 135.4 & 19.0 & 955 \\
\hline 55.3 & 57 & 43.4 & 0.01 & 125.3 & 184.6 & 25.1 & 2438 & 123.0 & 165.5 & 35.3 & 2379 \\
\hline 55.3 & 57 & 43.4 & 0.28 & 120.5 & 181.6 & 20.0 & 2394 & 118.0 & 160.7 & 25.0 & 2316 \\
\hline 55.3 & 57 & 43.4 & 168 & 120.1 & 169.0 & 14.3 & 2029 & [17.7 & 136.8 & 18.1 & 1828 \\
\hline 83.4 & 86 & 28.8 & $0.0 !$ & 162.6 & 219.9 & 50.0 & 3964 & 160.9 & 208.8 & 60.1 & 3885 \\
\hline 83.4 & 86 & 28.8 & 0.28 & 157.2 & 202.0 & 40.1 & 3966 & 155.4 & 188.0 & 45.8 & 3873 \\
\hline 83.4 & 86 & 28.8 & 168 & 154.0 & 169.0 & 40.0 & 3415 & 152.1 & 182.8 & 60.3 & 3338 \\
\hline 110.5 & 114 & 21.7 & 0.01 & 203.3 & 269.9 & 60.0 & 5725 & 201.9 & 262.7 & 60.0 & 5594 \\
\hline 110.5 & 114 & 21.7 & 0.28 & 192.5 & 247.5 & 50.2 & 5574 & 190.9 & 238.2 & 60.7 & 5430 \\
\hline 110.5 & 114 & 21.7 & 168 & 188.1 & 242.2 & 60.0 & 5548 & 186.4 & 233.6 & 70.4 & 5408 \\
\hline
\end{tabular}


Jength scale comparable to the distance between the hot and cold regions of the repository. Buoyant, gas-phase convection eells develop as the warmer, less-dense column of gas within the footprint of the WPs is displaced by the cooler. denser column of gas in the adjacent areas. As the initially cooler gas is heated up, its relative humidity is lowered, causing it to cvaporatc water from the rock matrix below hot regions of the repository. This warm moist air is convected upward to where it cools above the WPs. generating condensate that drains down fractures back toward the repository and/or is imbibed by the matrix, causing a saturation buildup above the WPs.

High AMLs result in a large zone of above-boiling temperalures that suppresses the effects of repositoryscalc, bunyant vapor flow: +." Sub-repository-seale, buoyant, gas-phase convection continues as long as significant temperature differences persisl within the repository. It can dominate moisture movement for up to 1000 yr for the drift spacing described in the Sitc Characterization PlanConceptual Design Repor (SCP-CDR). ${ }^{3.1 \times}$ The larger drift spacing that is consisient with the use of larger WPs will result in temperature differenees within the reposilory persisting longer. Consequently. the effects of subrepository-scule, buoyanı vapor flow will also be more persistent, possibly lasting thousands of years. In previous work. ${ }^{+}$we found that the threshold $k_{\mathrm{b}}$ where sub-repository-seale, bunyant vapor flow begins to dominate moisture movement is about I darcy. If. as Wecks ${ }^{\text {th }}$ suggests, $k_{\mathrm{h}}$ al the repository horizon is found to be on the order of 200 darcy, the impact of sub-repository-scale, buoyint. gas-phase convection will be extremely significant.

The most important observution about sub-repositoryseale performance concerns the substantial difference between thermal performance predicted by repositoryscale models and that predicted by drift-scale models. For an AML of 24.2 MTU/acre, the repositon -scule models predict a peak temperature, $T_{\text {peak, of }} 65^{\circ} \mathrm{C}$, while the driftscale models predict $T_{\text {peok }}$ of up $10171.8^{\circ} \mathrm{C}$ on the WP surface and $144.1^{\circ} \mathrm{C}$ in the rock adjacent to the drift. While the repository-suile model predicts no boiling period (Fig. 5b), the drift-scale model predicts a boiling period duration. $t_{\mathrm{hp}}$, of 183 to $202 \mathrm{yr}$ in the rock and from 300 to 350 yr on the WP surface (Table II). Similarly, the repository-scale model predicts no boiling period for an AML of 35.9 MTU/acre (Fig. 5a). However, the drift-scale model predicts ${ }_{h}$ of 955 to $1014 \mathrm{yr}$ in the rock and 1111 in 1155 yr on the WP surfuce (Table It).

Another imporant observation about sub-repositoryscale performance is that $T_{\text {peak }}$ varies modestly for AMLs ranging from 24.2 to 55.3 MTU/acre (Figs. 10 a and b). Because it oceurs so carly ( 12 to $25 \mathrm{yr}$ ), $T_{\mathrm{n} u \mathrm{kK}}$ is relatively insensitive to whether the distance to the adjacent emplaeement drift is $43.4 \mathrm{~m}$ or $99.0 \mathrm{~m}$. For the high AML.s, the drift spacing is small enough to cause $T_{\text {neak }}$ to be sensitive to center-10-center drift spacing. Consequently, $T_{\text {peak }}$ is significantly greater for the $110.5-\mathrm{MTU} /$ acre case than for the 83.4-MTU/acre case (Figs, 10a and b).

\section{V.B Sub-Repository-Scale Moisture Redistribution}

Figure II plots the dimensionless liquid saturation distribution orthogonal to an emplacement drift containing eilher (1) 21-PWR and 40-BWR WPs with a 12-m center-to-center spacing between WPs, or (2) 12-PWR and 21-BWR WPs with 6.86-m spacing between WPs. The center-10-center drift spacing is $99 \mathrm{~m}$, yiclding an AML of 24.2 MTU/acre. Figure 11 is plotted at $300 \mathrm{yr}$. which is about the end of the boiling period for the WP surface. For the uniform 10-millidarey case, boiling has resulied in a small dry-out zone surrounding the cmplacement drift (F:g. 1 ia), while for the uniform 168-darcy case, the dry-out zone is considerably larger (Fig. 11c). The difference in dry-out volume between these lwo cases

Figure 10. Temperalure history (a) on the WP surface, and (b) in the rock $0.75 \mathrm{~m}$ above the center of the drifi ceiling for $k_{h}=280$ millidarcy and various AML.s. The heating curve is a composile for 46 40-BWR WPs and 63 2I-PWR WPs received during the first two ycars of repository operation.

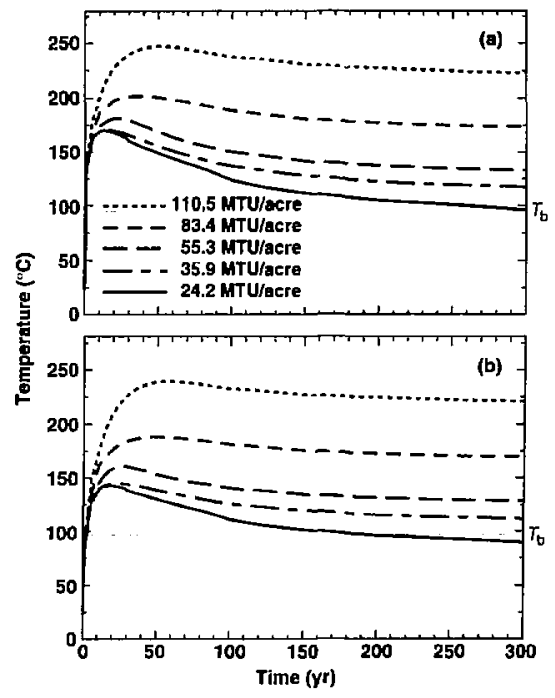


can be altributed to the influenee of sub-repository-seale, buoyant. gas-phase convection. Buoyant convection is also responsible for driving all of the condensulc buildup above the drift (Fig. 1/e). Buoyant convection contintes to drive significant vapor and condensalc flow for aboul 2000 yr (long after boiling conditions have ceased).

Many of our calculations $5^{\text {tr: }}$ have alssumed al homogeneous $k_{\mathrm{b}}$ distribution and therefore do not address how heterogeneity might cause focused vapor and condensate flow. In Fig. It b we use a highly idealized example to illustrate how heterogencity at the subrepository-scale might result in focused vapor and condensilte flow in the vicinity of an emplacement drift. In this example. a l,6-m-wide, high- $k_{\mathrm{h}}$ zone is aligned along the axis of the WP and flanked hy low- $k_{b}$ zones. The gas-phase pressure differential between these zones drives water vapor back toward the drift and into the high- $k_{\text {b }}$ zone. Waler vapor flows up the high- $k_{b}$ zone until it condenses and drains back down. Enough water vapor enters and condenses in this zone to cause the condensate drainage flux to be large conough to maintain sefluxing in the repository. The resulting heat-pipe effect enables the temperature at the top of the drift to remain at the nominal boiling point for the entire duration of the boiling period (about $300 \mathrm{yr}$ ), causing a depression in the dry-out zone. This refluxing zone persists for more than $2000 \mathrm{yr}$. Iong after boiling has ceased. This cximpic is similar to calculations conducted in a previous study. ${ }^{4}$ where we showed that spatial variability of hydrological properties can strongly influence therino-hydrological behavior under sub-boiling conditions. We applied the same three $k_{\mathrm{h}}$ distributions shown in Fig. 11 to AMLs of 24.2. 3.5.9. 55.3. 83.4, and $110.5 \mathrm{MTU} / \mathrm{acrc}$. For the 83.4- and 110.5-MTU/acre cases, the thermo-hydrological behavior was virtually the same for the three different $k_{\mathrm{h}}$ distributions.

In general, we found that $t_{\mathrm{pp}}$ is insensitive to subrepository-scale. huoyant. gas-phase convection for the low- and high-AML cises (24.2, 35.9, and I10.5 MTU/acru). For the intenmediate-AML cases ( 55.3 and 83.4 MTU/acre). hp is modestly sensitive to sub-repository-scale, buoyant. gas-phase convetion. For the high-AML cases, the exlent

Figure 11. Dimensionless liquid saluration distribution orthogonal to an emplacenent drift for an AML of 24.2 MTU/acre at $t=300$ yr. The heating curve is a composite for 46 40-BWR WPs and 63 21-PWR WPs received during the first two years of repository operation. Dimensionless licguid suturation distributions are shown for (a) a uniform $k_{\mathrm{b}}$ of 10 millidarey, (b) a heterogeneous $k_{\mathrm{h}}$ distribution consisting of allernating 1.6-m-wide. 168-darcy, high- $k_{\mathrm{h}}$ zones and 97.4-m-wide, 10-millidarcy zones, and (c) a uniform $k_{h}$ of 168 darey. The medium-shaded area surrounding the drift corresponds to a region that is drier than anbient situration (dry-out zone). The dark-shaded areas correspond to regions that are wetter than ambient saturation (condensation zones). The lighter shading surrounding the dark-shaded areas corresponds in a decreasing buildup in saturation (outer edges of condensation zones). No shaditg indicales no change in saturation.

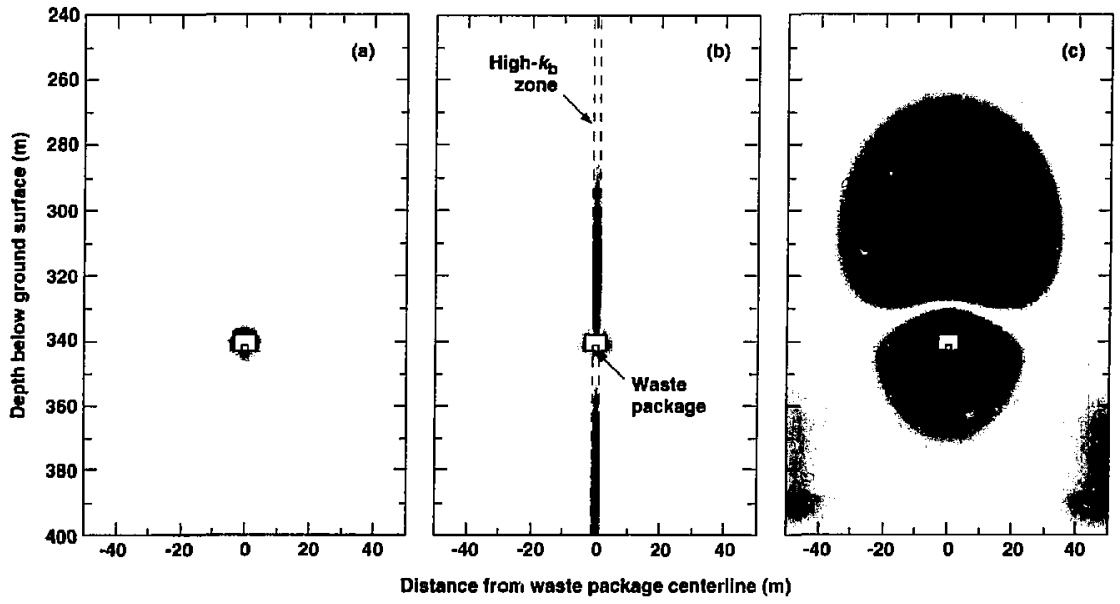


of dry-out is insensitive to sub-repository-scale, bunyant, gas-phase convection. For the low-AML cases, the cxicnt of moisture movement (i.e., dry-c.,t and condensate buildup) is extremely dependent on the magnitude of sub-repositoryscale, buoyant, gas-phase convection.

There has been considerable debate over what constitutes a "cold" repository. One view is that a "cold" repository is one in which local temperatures never exceed boiling. Another view is that it is only necessary for the average repository temperature never to exceed boiling. What is not usually stated, but sometimes implied, is that sub-boiling temperatures can be equated with the absence of significant repository-heat-driven effects. Our analyses show that boiling conditions can persist around an emplacement drift even if the average repesitory temperature is well below the boiling point. Morcover, if buoyant, gasphase convection is found to be significant, it can drive substantial vapor and condensate fluxcs whether or nol hoiling oucers. On the other hand, if buoyant. gas-phase convection is found to be insignificant, a boiling period of sufficiently limited duration may be shown to generate condensale fluxes that have a minor impact on performance. Howerer, the absence of local boiling conditions is not, in ilself, an adequate indicator of whether reposilory heat drives significant vapor and condensale now. Average repository temperatures are an even ponrer indicator of the significance of $\pi^{2}$ pository-heal-driven hydrol hermal fow in the performance of a low-AML repository. Diugnosing whether sub-boiling conditions can be equaled with the ahsence of significant reposilory-heal-driven effects wijl require in situ heater tests conducled under sub-boiling as well as above-boiling conditions. ${ }^{13.211}$

\section{V1. Conclusions}

The radioactiye heat-of-decay from spent nuclear fuel will play a dominant role in the performance of a polential repository at Yucca Mountain. Coupled hy'drothermalgeochemical processes can sirongly affect the composilion and flow rates of gas and liquid around the waste packages. Waste package degradation, waste-form dissolution, and radionuclide relcase will eritically depend on these processes. Repository heat will also play a dominant role in the evolution of the flow field that will drive gas-phase and liquid-phase transport. In addition, coupled hydrothermalgeochemical phenomena may significantly affect the perfomance of natural barriers underlying the repository. Depending on the thermal-loading management strategy (w'hich will affect the design and operation of the repository) and site conditions, repository heat may either substantially increase the likelihood of water contacting waste packages and the magnitude of release and transpon of radionuclides or preclude, or at least minimize, these effects for some period of time.
In our modeling studies, our approach has been to identify conditions that could potentially generate adverse performance. Accordingly, we have considered a wide range of bulk permeability values and examples of heterogeneity that may be extremc. This work provides a context for understanding the relative importance of various hydrogeological properties and features that will be determined during site characterization. This work also shows that the challenge of adequately understanding repository-heat-driven vapor and condensate flow is at least as formidable for subboiling conditions as it is for above-boiling conditions. Long-term in situ heater tests, conducted under both sub-boiling and abovc-boiling conditions, are required to determine the potential for the major repository-heatdriven sources of fracture flow to impact waste package performance and radionuclide transport.

\section{Acknowledgments}

The authors acknowledge the helpful comments of sim Blink during the past year and the revies' of Blll Halsey. We ucknou'ledge the very powerful postprocessing softu'arc developed by Stephanic Daveler. We also appreciatc the assislance of Rick Wooten. who prepared the graphies, and the cditorial assistance of Jay Cherniak. We also thank Marion Capobianen for assisting in the text liyout. This work was supported by the Near-field Hydrology Tusk (WBS 1.2.1.5) of the Yucca Mountain Sile Characterization Projecl. Work performed under the auspices of the U.S. Department of Energy by Lawrence Livermore National Laboratory under Comtract W-7405-Eng-48.

\section{References}

J. Montazer, P., and W.E. Wilson, "Conceptual Hydrologic Model of Flow in the Unsaturated Zone, Yucca Mountain, Nevada," Water Rescources Investigation Report 84-4345, U.S. Geological Survey (1984).

2. Klavetter, E.A., and R.R. Peters, "Estimation of Hydrologic Propertics of an Unsaturated Fractured Rock Mass," SAND84-26-12, Sandia National Laboralories, Alhuquerque, NM (1986).

\section{Satcrlic, S.F., and B. Thompson, "FY93 Thermal Loadiug Systems Study Finat Report, Volume 1," prepared by Civilian Radioactive Woste Management System Management and Operating Contractor, TRW Environmental Safety Sysiems, Inc., Las Vegas, NV, December 30, 1993.}


4. Buscheck. T.A., and J.J. Nitao, "The Impact of Repository Heal on Thermo-Hydrological Performanrc at Yucca Mountain," Proceedings American Naclear Society Topical Mo'ting on Site Characterization and Model Volidation (Frows 93), Las Vegas, NV, Sept. 26-30, 1993.

5. Pruess, K., and Y.W. Tsang, "Modeling of Strongly Heat-Driven Processes at a Polential High-Level Nuclear Waste Repository at Yucea Mountuin, Nevada," Proceedings Fourth luternational High-Level Radioactive Waste Management Conference, Las Vegas, NV, April, 1993.

6. Buscheck. T.A., anti J.J. Nitao, “The Impact of Thermal Loading on Repository Performance al Yucca Mountuin," American Nuclear Socicty, Preccedings Third International High-Level Reddioncril'e' Waste Management Conference, Las Vegas, NV, April 12-16, 1992. Also, UCRL-JC-109232, Lawrence Livermore National Laboratory, Livermore, CA ( 1992).

7. Buscheck, T.A., and J.J. Nitio, "The Impact of Repository-Heat-Driven Hydrothermal Fluw on HydroJogical Performance at Yucca Mountain," American Nuclear Suciely, Prre'edings Fourth Imernational HighLevel Radiractive Waste Monergemem Conference, Las Vegas, NV. April 1993. Also, UCRL-JC-//244t. Lawrence Livermore Nalional Laborutory, Livermore. CA (1993).

8. Buscheck, T.A., and J.J. Nólao, "Repository-HeatDriven Hydrothermal Flow at Yucca Mountain, Pan l: Modeling and Analysis." Nicklear Ter huology, Vol. 104. No. 3. pp. 418-448 (1993).

9. Buscheck, T.A., and J.J. Nitao, "The Impact of Buoyant

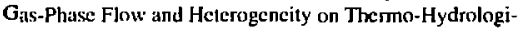
cal Bchavior at Yucca Mountain," American Nuctear Sccicly. Proceeding. Fifth International High-Level

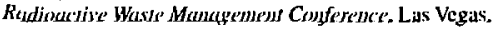
NV, May 1994. Also, UCRL-JC-11535/. Liwrence Livermore National Luboratory. Livermore, CA (1994).

10. Nitao. J.J., "V-TOUGH - An Enhanced Version of the TOUGH Code for the Thermal and Hydrologic Simulation of Large-Scale Problems in Nuclear Waste Isolation." UCID-2195.t. Lawrenee Livermore National Luboratory. Livermore, CA (1989).

11. Pruess, K. "TOUGH User"s Guidc," NUREG/CR4045. Nuclcar Regulatory Commission (1987).
12. Pctcrs, R.R., E.A. Klavetler, I.J. Hall, S.C. Blair, P.R. Hellers, and G.W. Gec, "Fracture and Mutrix Hydrologic Characteristics of Tuffaceous Materials from Yucca Mountain, Nye County, ivevada," SAND84-1471. Sandia National Laboratories, Albuquerque, NM (1984).

13. Buscheck:, T.A., J.J. Nitio, and D.A. Chesnut, "The Impact of Episodic Nonequilibrium Fracture-Matrix Flow on Geulogical Repository Performance," Proceedings American Nuclear Society Topical Mecting on Niclear Wawt Packuging (Fortur 9l), Las Vegas. NV. Sept. 30-Oct. 2, 1991. Also, UCRL-JC-J06759, Lawrence Livermore National Laboratory, Livennorc, CA (1991).

14. DOE (U.S. Dept. of Energy). "Yucca Mountain Project Reference Information Base," YMP/CC-0002 (Version 04.002), Nevada Operations Office, Las Vegas, NV (1990).

15. King. J.. "Data Transmittal for Phase 2 Themal Loading Study." Interoffice Correspondence, VA.SE.JK.S/ 93.031, prepared by Civilian Radioactive Wastc Management System Management and Operating Contractor. TRW Safety Systems, Inc., Vienna, VA. May 24. 1993.

16. Wecks, E.P., "Gas-Phase Flow at Yueca Mountain." presentation to the National Academy of Sciences" Committec on the Tethnical Basis for Yucce Mountain Slandurds, Nutienul Researth Conncil, December I6. 1993.

17. Wecks. E.P., personal communiluation, U.S. Geological Survey, Denver. CO (1993).

18. SNL (Sandia National Laboratt)ries), "Site Characterizalion Plan - Conceptuil Design Report," SAND87-26-11, Sandia National Laboratories, Albucquerque. NM (1987).

19. Buscheck. T.A., D.G. Wilder, and J.J. Nituo, "LargeScale In Silt Heater Tests for the Characterization of Hydrothermal Flow al Yucca Mountain." American Nuclear Socicty, Procesdings Fourth Imermational High-Le'vel Radioucrite Wasro Managemem Comference, Las Vegas, NV, April 1993. Also, UCRL-JC-1/24+5, Lawrence Livermore National Laborakory, Livenmore, CA (1993).

20. Buscheck. T.A., D.G. Wilder, and J.J. Nitao, "Repository-Heat-Driven Hydrothemal Flowv at Yucca Mountain, Par 1l: Large-Seale hi Sim Heater Tests," Nuclear Technolagy, Vol. 104. No. 3, pp. 449-47I (1993). 